\title{
Beneath the Dryland
}

\section{Kenya Drought Gender Analysis}

\author{
Oxfam - December 2017
}

Maria Libertad Mella Dometita, Gender Adviser - Humanitarian Support Personnel

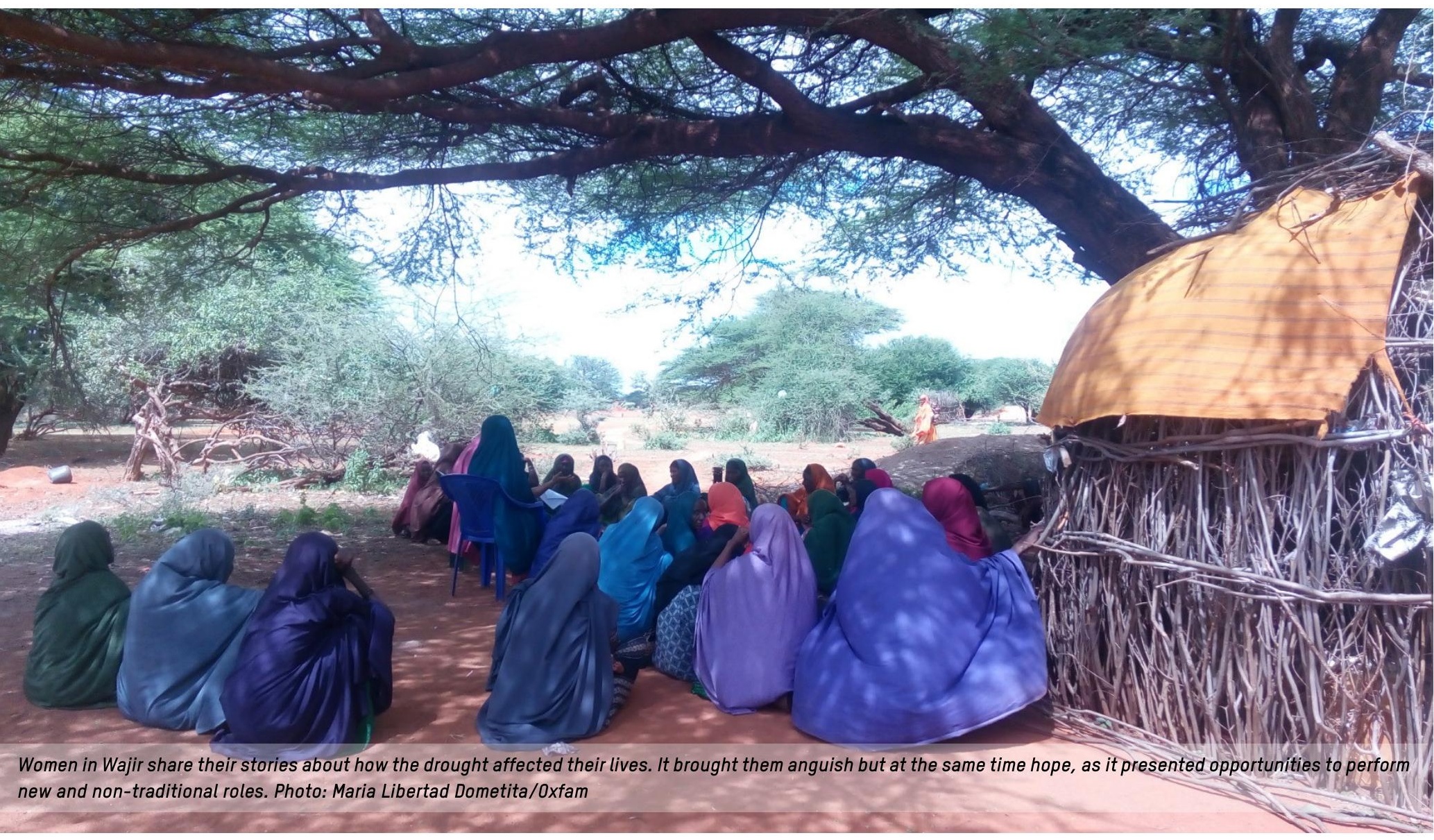




\section{Oxfam Research Reports}

Oxfam Research Reports are written to share research results, to contribute to public debate and to invite feedback on development and humanitarian policy and practice. They do not necessarily reflect Oxfam policy positions. The views expressed are those of the author and not necessarily those of Oxfam.

For more information, or to comment on this report, email Maria Libertad Mella Dometita at mdometita@oxfam.org.uk.

(C) Oxfam International December 2017

This publication is copyright but the text may be used free of charge for the purposes of advocacy, campaigning, education, and research, provided that the source is acknowledged in full. The copyright holder requests that all such use be registered with them for impact assessment purposes.

For copying in any other circumstances, or for re-use in other publications, or for translation or adaptation, permission must be secured and a fee may be charged.

Email policyandpractice@oxfam.org.uk.

The information in this publication is correct at the time of going to press.

Published by Oxfam GB for Oxfam International under ISBN 978-1-78748-154-1 in December 2017.

\section{OXFAM}

Oxfam is an international confederation of 20 organizations networked together in more than 90 countries, as part of a global movement for change, to build a future free from the injustice of poverty. Please write to any of the agencies for further information, or visit www.oxfam.org. 


\section{ACKNOWLEDGMENTS}

Oxfam is very grateful to the women and men affected by the drought in the Kenyan counties of Turkana and Wajir who participated in the focus group discussions, surveys and interviews in this gender analysis report.

Oxfam would also like to thank other respondents to this report: Oxfam staff in Turkana and Wajir, and staff at UNHCR, INGOs, NGOs and the county governments of Turkana and Wajir.

This gender analysis would not have been successful without the contribution of Oxfam staff, especially: Sumananjali Mohanti (Country Director, Kenya), Nicole Ochando (former Humanitarian Support Personnel Programme Manager, Kenya), Emmanuel Kivunga (MEAL Coordinator, Kenya), Irene de Leon (former Country MEAL Coordinator, Philippines), Rose Tino Otim (Turkana Programme Coordinator, Kenya), Tess Dico-Young (GHT Global Gender Adviser) and Romane Bonneme (GHT Gender Support Officer). Thank you for your contributions and critical feedback. 


\section{CONTENTS}

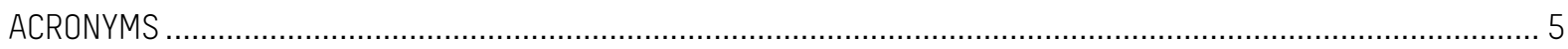

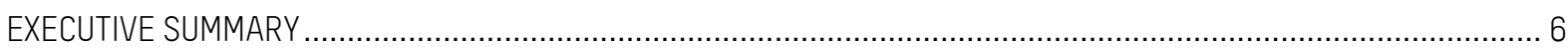

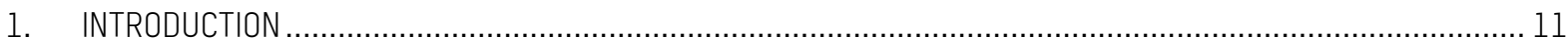

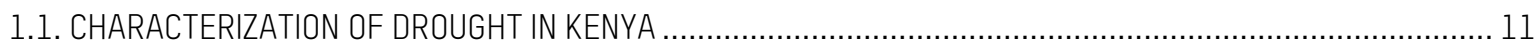

1.2. GENERAL UNDERSTANDING ABOUT THE 2016-17 DROUGHT …………………........................... 11

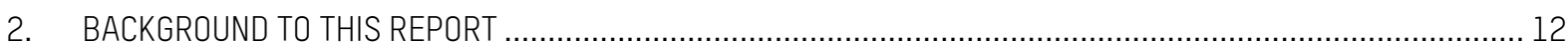

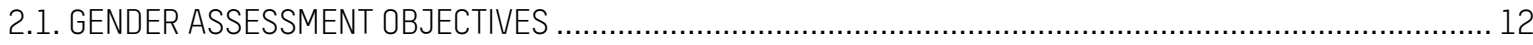

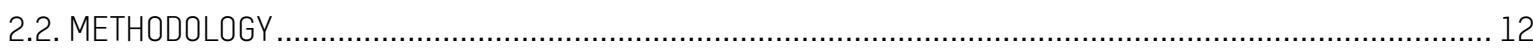

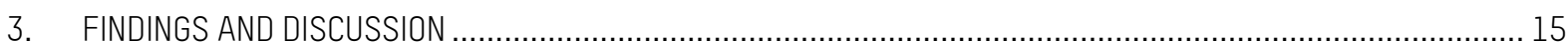

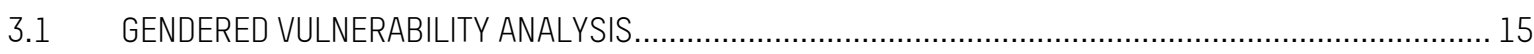

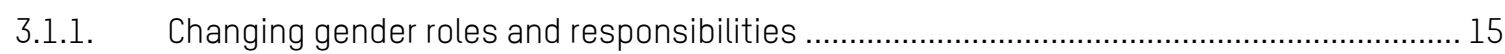

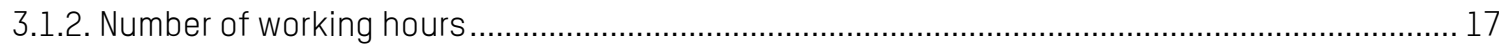

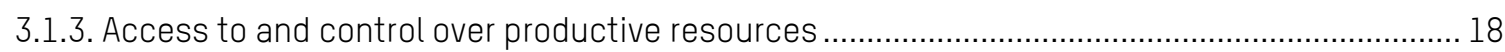

3.1.4. Decision making and participation in households ........................................................ 19

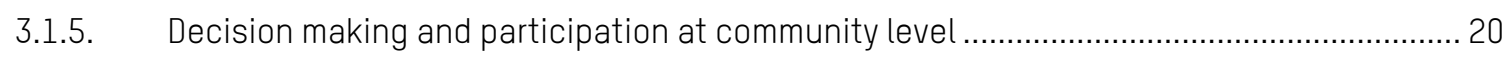

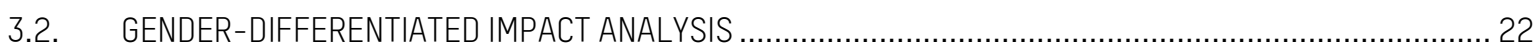

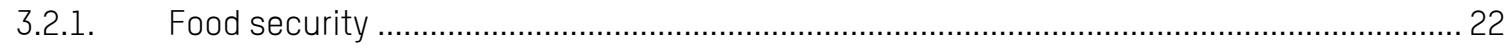

3.2.2. Livelihoods, livelihood shifts and implications for men and women................................... 25

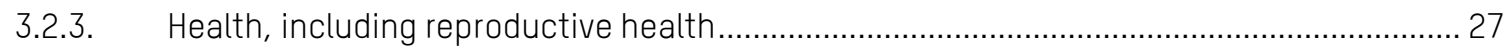

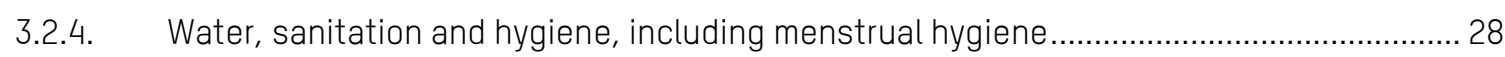

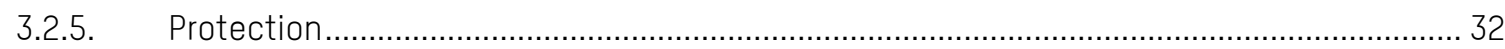

3.3. GENDERED-DIFFERENTIATED COPING CAPACITIES AND STRATEGIES ............................................... 34

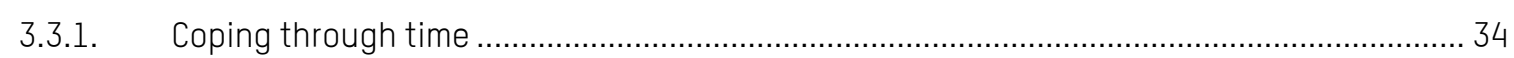

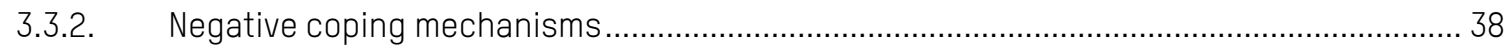

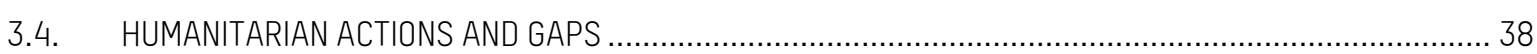

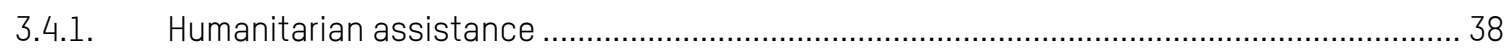

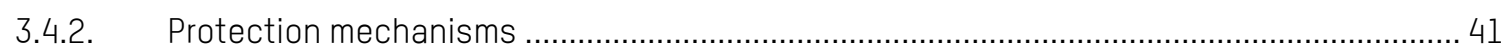

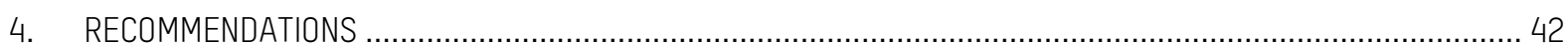

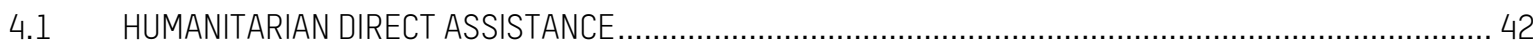

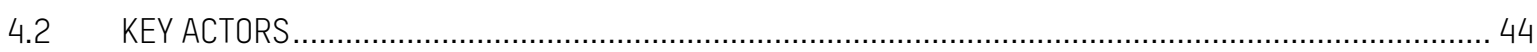

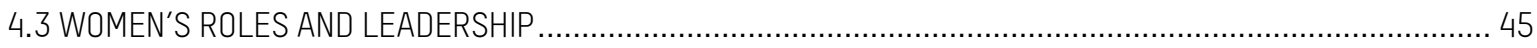

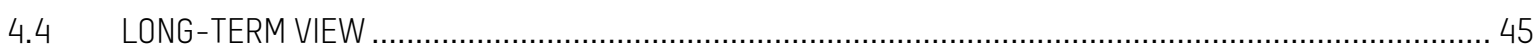

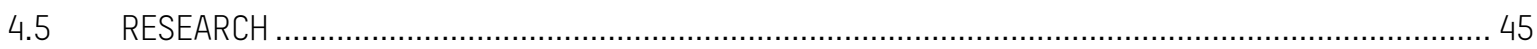

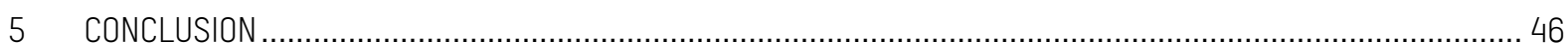

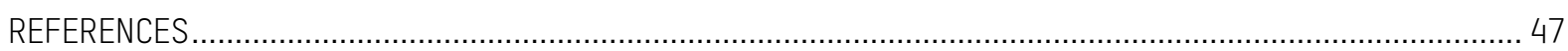

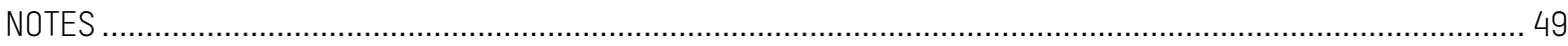




$\begin{array}{ll}\text { ACRONYMS } \\ \text { ASAL } & \text { Arid and semi-arid land } \\ \text { CEDAW } & \text { Convention on Elimination of all Forms of Discrimination Against Women } \\ \text { CLTS } & \text { Community-led total sanitation } \\ \text { CSG } & \text { County Steering Group } \\ \text { CSO } & \text { Civil Society Organization } \\ \text { CTP } & \text { Cash Transfer Programme } \\ \text { FGD } & \text { Focus group discussion } \\ \text { IRC } & \text { International Rescue Committee } \\ \text { KII } & \text { Key informant interview } \\ \text { NDMA } & \text { National Drought Management Authority } \\ \text { NFI } & \text { Non-food item } \\ \text { NGO } & \text { Non-Governmental Organization } \\ \text { OCHA } & \text { The United Nations Office for the Coordination of Humanitarian Affairs } \\ \text { RH } & \text { Reproductive health } \\ \text { SGBV/GBV } & \text { Sexual and gender-based violence/Gender-based violence } \\ \text { TWADO } & \text { Turkana Women Advocacy and Development Organization } \\ \text { TWCC } & \text { Turkana Women Conference Centre } \\ \text { UNHCR } & \text { Wérinaires Sans Frontières - Germany } \\ \text { WASH } & \text { Woter, Sanitation and Hygiene } \\ \text { WRO Organization }\end{array}$




\section{EXECUTIVE SUMMARY}

In the arid and semi-arid land (ASAL) counties of Kenya, people are experiencing a food security and nutrition crisis as the drought has worsened since August 2016. The number of food-insecure people reached 2.7 million in July 2017, including 375,285 children and pregnant and breast-feeding women. ${ }^{1}$ The drought has undermined coping capacities and exacerbated vulnerabilities le.g. by destroying livelihoods and triggering local conflicts over scare resources). Most of the respondents in the two ASAL counties studied in this report, Turkana and Wajir, recognized that a number of coping mechanisms had various detrimental effects on individuals and the whole community. Because of these effects, there is an increase in children who need educational assistance; ${ }^{2}$ protection issues are worsening (with women more likely to face sexual violence when travelling longer distances or within households); and boys and men are largely affected by conflict and crime. Finally, disease outbreaks have reached an unprecedented level and medical lifesaving interventions are needed. ${ }^{3}$ The drought has also exacerbated gender-specific problems, with different physical and psychological issues for women and men.

\section{Objectives of the gender analysis and methodology}

\section{- Specific objectives}

- To understand the gender differences: identify different gendered needs and interests, risks, vulnerabilities and capacities; identify and understand challenges and how people cope; understand context and identify opportunities for increasing agency, voice and participation and economic empowerment

- To identify capacities of duty bearers in responding to the needs of the affected population by providing humanitarian services

- To understand the interactions between and among affected people and duty bearers

\section{- Methodology}

- Qualitative data collection methods carried out in drought-affected areas in Wajir and Turkana:

- Key informant interviews (KIIs): targeting 12 community leaders at the village level and 19 representatives at the county level

- Focus group discussions (FGDs): separate groups of women and men from each village, totalling 22 FGDs (11 women's groups and 11 men's groups)

- Quantitative data collection: desk review of related literature

\section{Key findings and recommendations}

\section{- Humanitarian direct assistance}

\begin{tabular}{|l|l|l|}
\hline $\begin{array}{l}\text { Food } \\
\text { security }\end{array}$ & $\begin{array}{l}\text { Findings } \\
\text { The elderly, women, infants and } \\
\text { affegnant/lactating women are the most by food insecurity. }\end{array}$ & $\begin{array}{l}\text { Food aid is within the control of women, } \\
\text { and cash aid is controlled by men. A } \\
\text { combination of food, non-food and cash } \\
\text { interventions lconditional or unconditional } \\
\text { children and men are prioritized within } \\
\text { the household for food intake. }\end{array}$ \\
$\begin{array}{l}\text { More women are sacrificing food intake: } \\
\text { eating less-preferred/less expensive } \\
\text { foods; limiting their intake in order for } \\
\text { children to eat; cutting the size of meals, } \\
\text { skipping meals or not eating for a whole } \\
\text { day. }\end{array}$ & $\begin{array}{l}\text { Cash Transfer Programme (CTP) } \\
\text { To support more pastoral-related } \\
\text { activities } \\
\text { To include gender-specific work } \\
\text { such as cash for work that targets } \\
\text { women } \\
\text { To explore supporting cash for } \\
\text { women's leadership, or cash for }\end{array}$ \\
\hline
\end{tabular}




\begin{tabular}{|c|c|c|}
\hline & & $\begin{array}{l}\text { supporting women to be gender } \\
\text { advocates } \\
\text { To explore cash support for youth: } \\
\text { male/female gender community } \\
\text { mobilizers } \\
\text { To provide alternatives such as food } \\
\text { vouchers if suppliers are accessible } \\
\text { and transaction costs are not carried } \\
\text { by beneficiaries } \\
\text { To give different aid packages that } \\
\text { facilitate opportunities for women to } \\
\text { access and control resources }\end{array}$ \\
\hline Livelihoods & $\begin{array}{l}\text { The drought has brought shifts in } \\
\text { livelihoods and traditional gender roles. } \\
\text { Women are more involved in productive } \\
\text { activities (more involved in casual } \\
\text { labour). } \\
\text { Men are more open to reproductive roles, } \\
\text { even though they are very selective le.g. } \\
\text { collecting firewood to sell and for } \\
\text { charcoal burning, domestic work such as } \\
\text { cooking or fetching water, taking care of } \\
\text { children and nursing ill family members). } \\
\text { Decisions to sell animals are being made } \\
\text { jointly and not just by the men. } \\
\text { Children are often helping, usually in } \\
\text { roles ascribed to their respective } \\
\text { genders. } \\
\text { Income from casual labour is very low, } \\
\text { due to: loss of remaining assets and } \\
\text { natural resources, decline in customers, } \\
\text { increase in food prices and ultimately } \\
\text { debts. Economic dependency on } \\
\text { relatives is increased. }\end{array}$ & $\begin{array}{ll}\text { - } & \text { To support remaining livelihood assets } \\
\text { - } & \text { To create a gendered value-chain } \\
\text { analysis to understand gender- } \\
\text { specific livelihoods } \\
\text { - } \\
\text { To support access to markets with } \\
\text { fewer barriers to entry for women and } \\
\text { other vulnerable groups } \\
\text { - To support non-pastoral/new } \\
\text { livelihood activities (petty businesses } \\
\text { and casual labour) } \\
\text { To promote households' livelihood } \\
\text { diversification by engaging both } \\
\text { women and men to strengthen } \\
\text { economic resilience } \\
\text { To seek ways of supporting } \\
\text { reproductive activities (care work) } \\
\text { where women are also engaged in long } \\
\text { hours on productive work }\end{array}$ \\
\hline $\begin{array}{l}\text { WASH } \\
\text { (Water, } \\
\text { Sanitation } \\
\text { and Hygiene) }\end{array}$ & $\begin{array}{l}\text { There are strict traditions and norms, } \\
\text { linked to gender roles, which govern } \\
\text { behaviours and decisions about water } \\
\text { collection, defecation and bathing. } \\
\text { The main water collectors to borehole or } \\
\text { water points are women and girls, who } \\
\text { carry the water themselves lon the back } \\
\text { or head) while men use a pull-cart and } \\
\text { animal. } \\
\text { Access to latrines is limited: there is } \\
\text { insufficient lighting, no separation } \\
\text { between male/female toilets, no locks or } \\
\text { partition doors for privacy. Women } \\
\text { expressed fear and humiliation as there } \\
\text { is no privacy from men, and they often } \\
\text { decide to wait to use latrines at night. }\end{array}$ & $\begin{array}{l}\text { - } \text { To include 'barriers' to markets for } \\
\text { conditional cash for water, such as } \\
\text { transaction and transportation costs } \\
\text { - To explore culturally appropriate and } \\
\text { locally accessible menstrual hygiene } \\
\text { management needs } \\
\text { - To follow international standards with } \\
\text { regards to latrine and bathing facilities } \\
\text { when it comes to practical, social and } \\
\text { cultural issues le.g. locks, gender } \\
\text { separation) }\end{array}$ \\
\hline
\end{tabular}




\begin{tabular}{|c|c|c|}
\hline & $\begin{array}{l}\text { Since the drought started, although the } \\
\text { use of menstrual hygiene products has } \\
\text { increased, challenges remain in terms of } \\
\text { being able to afford sanitary towels and } \\
\text { having access to water for } \\
\text { cleaning/bathing. }\end{array}$ & \\
\hline $\begin{array}{l}\text { Non-food } \\
\text { Items (NFIs) }\end{array}$ & $\begin{array}{l}\text { Jerry cans, clothing and cooking utensils } \\
\text { are the top three NFIs that respondents } \\
\text { report they need most during these } \\
\text { times. } \\
\text { Items related to domestic activities are } \\
\text { more needed for women, as they assume } \\
\text { most household chores. }\end{array}$ & $\begin{array}{l}\text { - To include kitchen utensils as one of } \\
\text { the three most needed NFIs } \\
\text { To provide gender-specific NFIs } \\
\text { lespecially to pregnant and breast } \\
\text { feeding women, infants and elderly) }\end{array}$ \\
\hline $\begin{array}{l}\text { Health / } \\
\text { Reproductive } \\
\text { health }\end{array}$ & $\begin{array}{l}\text { Four distinctive health challenges } \\
\text { created/reinforced by the drought: } \\
\text { - } \quad \text { Common illnesses affecting women } \\
\text { and men (tuberculosis, pneumonia, } \\
\text { malaria, arthritis, and ulcers) } \\
\text { - } \quad \text { Gender-specific health problems: } \\
\text { men are identified as having more } \\
\text { reproductive issues (prostate } \\
\text { problems and difficulty in urinating, } \\
\text { erectile dysfunction) } \\
\text { - High levels of HIV/AIDS } \\
\text { - High levels of stress: women are } \\
\text { overworked, some men complain of } \\
\text { exhaustion from hard labour. Most } \\
\text { important is the prevalence of } \\
\text { mental stress for men, related to the } \\
\text { fear of not being able to provide for } \\
\text { their families }\end{array}$ & $\begin{array}{ll}- & \text { To consider psycho-social } \\
\text { interventions (mental stress) } \\
\text { - } \quad \text { To target reproductive issues that } \\
\text { affect both women and men }\end{array}$ \\
\hline Protection & 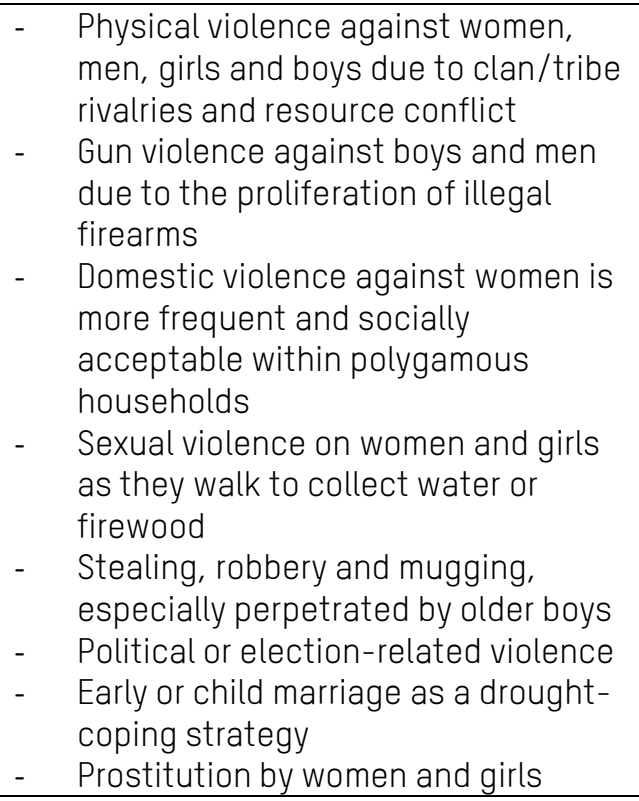 & $\begin{array}{ll}\text { - } & \text { To conduct a separate protection } \\
\text { assessment } \\
\text { - } \\
\text { To support referral pathways and } \\
\text { access to services } \\
\text { - } \quad \text { To invest in awareness-building and } \\
\text { preventive activities }\end{array}$ \\
\hline $\begin{array}{l}\text { Women's } \\
\text { roles and } \\
\text { leadership }\end{array}$ & $\begin{array}{l}\text { Women are increasing community roles } \\
\text { because of the opportunities given by aid } \\
\text { agencies. However even though they sit } \\
\text { as representatives, women's issues are } \\
\text { not on the agenda and women often } \\
\text { choose to be passive in the discussions, }\end{array}$ & $\begin{array}{l}\text { - To ensure more systematic awareness } \\
\text { and capacity building on gender } \\
\text { equality and women's rights (targeting } \\
\text { and engaging men and boys) } \\
\text { - To ensure women's voices are heard, } \\
\text { and to create spaces for women's } \\
\text { leadership and representation at }\end{array}$ \\
\hline
\end{tabular}




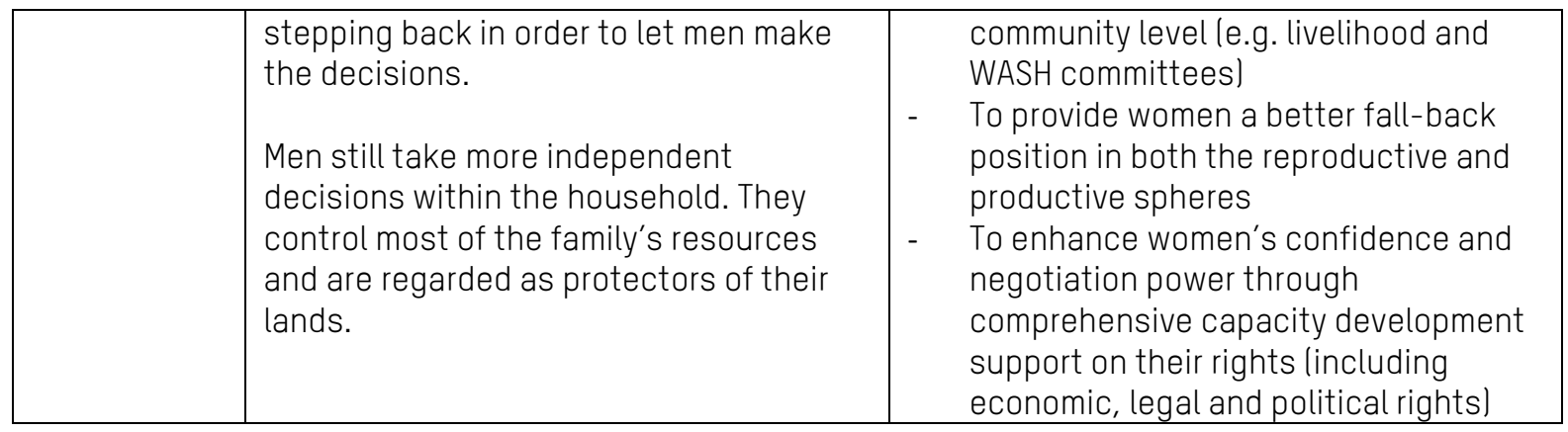

\section{- Roles of key actors}

Gender inequality does not only happen during a crisis. There is a need for comprehensive and effective gender mainstreaming as well as standalone women's rights programmes. The gains made on gender equality in a humanitarian response must be taken over by long term actors and institutions. It is imperative to connect up humanitarian and development programming.

\begin{tabular}{|c|c|}
\hline Government agencies & $\begin{array}{l}\text { - To introduce/strengthen government competency on gender } \\
\text { mainstreaming, especially the leadership of the Country Steering Group, } \\
\text { National Drought Management Authority (NDMA) and Disaster } \\
\text { Management department of county. } \\
\text { - To strengthen the capacity of sector-specific agencies who are leading } \\
\text { a sector-specific response (e.g. Ministry of Health, Ministry of Water). } \\
\text { - To strengthen humanitarian coordination systems: to include the } \\
\text { establishment of a Gender in Humanitarian Response working group. If } \\
\text { one already exists, it should be strengthened and given the mission to } \\
\text { lead gender coordination in response and recovery. }\end{array}$ \\
\hline UN agencies & $\begin{array}{l}\text { - To support in terms of strengthening capacity and coordination, as well } \\
\text { as influencing their respective counterparts. }\end{array}$ \\
\hline INGOS & $\begin{array}{l}\text { - } \quad \text { To come together to raise funds (e.g. a consortium). } \\
\text { - } \quad \text { To give special attention to Women's Rights Organizations (WROs): } \\
\text { looking at how they interact with the humanitarian response, and } \\
\text { supporting their capacities. }\end{array}$ \\
\hline Local NGOs & $\begin{array}{l}\text { - To ensure capacity building on more specific gender mainstreaming or } \\
\text { gender-targeted actions. }\end{array}$ \\
\hline Donors & $\begin{array}{l}\text { To prioritize the funding of gender analysis in assessment, monitoring } \\
\text { and review; as well as actions that respond to gender-differentiated } \\
\text { needs. } \\
\text { To ensure that funding is sustained, from response to recovery, for } \\
\text { gender mainstreaming and prevention of gender-based violence (GBV); } \\
\text { and for ensuring shifts in attitudes and promotion of women's } \\
\text { leadership. }\end{array}$ \\
\hline
\end{tabular}




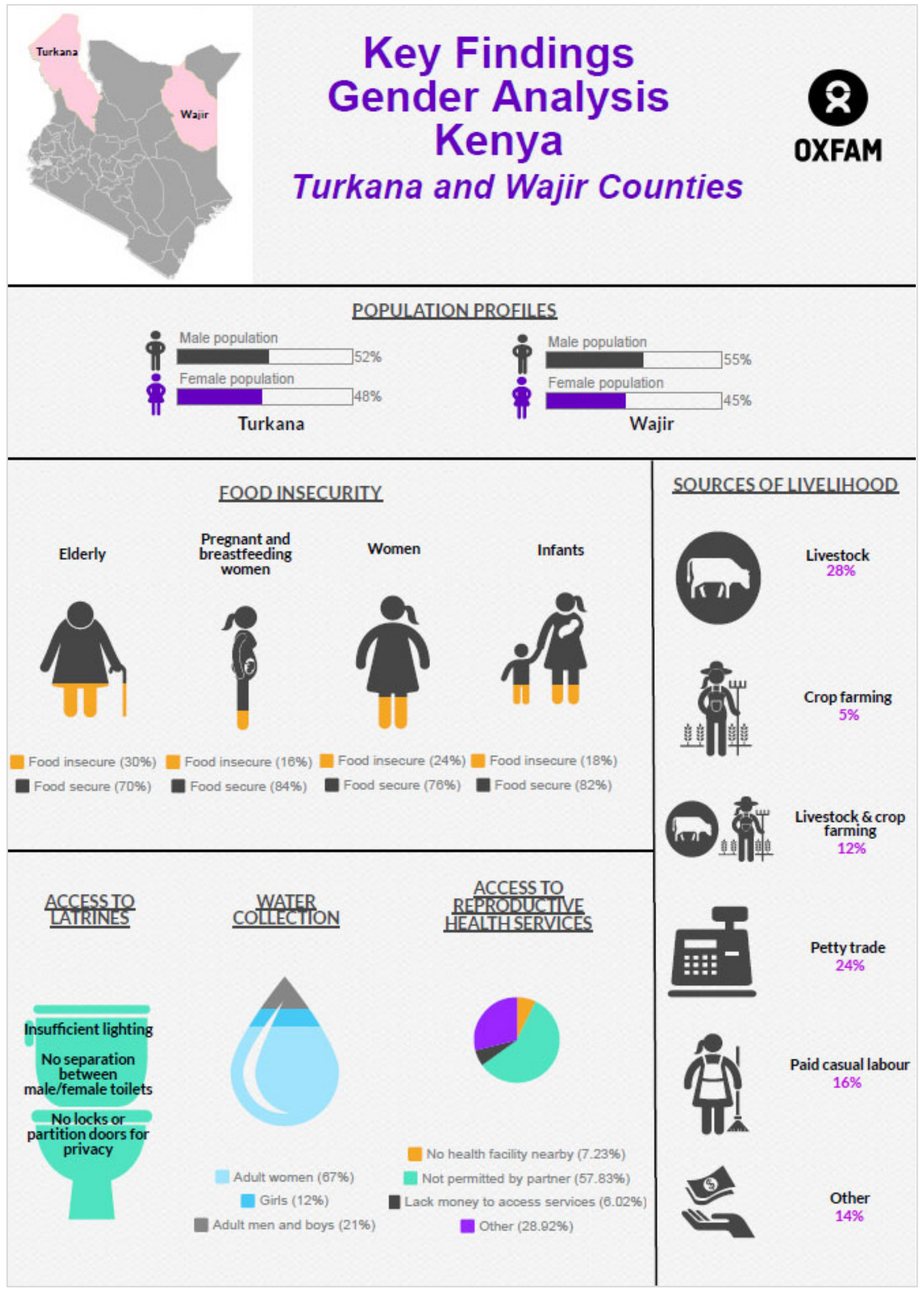




\section{INTRODUCTION}

Since August 2016, the drought situation in Kenya has worsened. During the short rain season there was no rainfall in ASAL counties. ${ }^{4}$ On 10 February 2017, the Government of Kenya declared a national drought emergency, with 23 out of 47 counties affected. The number of food-insecure people more than doubled from 1.3 million to 2.7 million. Some 357,285 children and pregnant and breast-feeding mothers are now acutely malnourished. ${ }^{5}$

More than 2.6 million Kenyans were severely food insecure as of 26 May 2017, with this figure rapidly rising. High levels of malnutrition are currently prevalent across the arid and semi-arid lands. Three sub-counties report Global Acute Malnutrition rates of 30 per cent ${ }^{6}-$ double the emergency threshold. Severe drought has dried up water resources in half of Kenya's 47 counties and an estimated three million people lack access to clean water. Recurrent droughts have destroyed livelihoods, triggered local conflicts over scarce resources and eroded the ability of communities to cope. Families are on the move, which poses protection risks for women and children. More than 1.2 million children are in need of education assistance. ${ }^{7}$ Kenya is experiencing multiple disease outbreaks, including cholera, acute watery diarrhoea and measles. An estimated 2.9 million people require lifesaving medical interventions and community-based primary health outreach. ${ }^{8}$ A substantial part of Kenya is becoming a dryland.

\subsection{CHARACTERIZATION OF DROUGHT IN KENYA}

The drought cycle in Kenya dates back to more than three decades ago. In 1975, widespread drought affected 16,000 people. In 1977, it was 20,000 people affected; in 1980, 40,000 people suffered the effects of drought, and in 1983/84 it hit over 200, 000 people. In 1991/92 in ASAL districts of North Eastern Kenya, the Rift Valley, Eastern and Coastal Provinces, 1.5 million people were affected by drought. It was reported that widespread drought affected 1.4 million people in 1995/96 and in 1999/2000, famine affected close to 4.4 million people. In 2004, three million people were in dire need of relief aid for eight months from August $2004-$ March 2005 due to widespread drought. The drought in 2008 affected 1.4 million people. In late 2009 and early 2010, 10 million people were at risk of hunger after harvests failed due to drought. ${ }^{9}$ From the aforesaid, it is evident that Kenya has been hit by repeated droughts. The drought cycle has become shorter, with droughts becoming more frequent and intense due to global climate change and environmental degradation. The cycle has reduced over the years, from every 10 years, down to every five years, further down to every two to three years, and currently every year is characterized by some dry spell. ${ }^{10}$ Kenya's agricultural production has been very erratic and seems to be facing more and more shocks due to drought. ${ }^{11}$ According to a study on the meteorological drought severity in Turkana between 1950 and 2012, 'it seems clear from the data presented and discussed here, that drought is the absolute norm in Turkana territory and "good" or "normal" years are the abnormality.' ${ }^{12}$

\subsection{GENERAL UNDERSTANDING ABOUT THE 2016-17 DROUGHT}

FGD participants were very aware of the drought, as this was not the first time they had experienced it. Many considered the current drought as one that had been continuing for at least a year. Over the past three to six years, they said that there had been more short rains than long ones. Over the past year, water had dried up, grass had disappeared and taken a long time to re-grow, and there were more deaths among livestock. They also reported that some livestock illnesses were new to them.

In Wajir, FGD participants called this drought Layaab, meaning 'wonder' in Somali (because they wonder about the massive illnesses and deaths among animals). Others referred to it as Iskugoor, a Somali word for people migrating from all over the county to another area with green pasture and water. In Turkana, they used the local term Torija, meaning 'it has cleared all the livestock'. They also consider this drought as a 'brother' of the droughts Kimirikand Lopiar; two very intense previous droughts. 


\section{BACKGROUND TO THIS REPORT}

When a disaster hits or a conflict erupts, humanitarian actors move quickly to save lives, meet basic needs and protect survivors. In this rush to provide a humanitarian response, the appeal to pay attention to gender issues often falls on deaf ears and may seem irrelevant. 'Paying attention to gender issues' or 'putting on a gender lens' quite simply means recognizing the different needs, capacities and contributions of women, girls, boys and men. Ignoring or being blind to these different needs can have serious implications for the protection and survival of people caught up in humanitarian crises. ${ }^{13}$

This gender assessment of the drought in Kenya is Oxfam's contribution to systematically gather and examine qualitative information on gender differences and social relations, in order to identify, understand and redress inequities based on gender within the humanitarian response. It is independently done but complementary to other emergency assessments being conducted by Oxfam, as well as other humanitarian agencies.

\subsection{GENDER ASSESSMENT OBJECTIVES}

The aim of the assessment is to understand the immediate and comparable gender-related impact of the 2016/2017 drought on women and men, and to some extent girls and boys, and how they respond to and interact with the crisis. The analysis will inform current and future Oxfam programming, advocacy and internal practices, and inform the wider humanitarian response.

\section{Specific objectives}

1. To understand the gender differences (needs, interest, coping mechanisms, capacities, roles, relations, risks, vulnerabilities) of women and men, girls and boys; and how they are affected by the drought.

a) Identify different gendered needs and interests, risks, vulnerabilities and capacities

b) Identify and understand challenges and how people cope

c) Understand context and identify opportunities for increasing agency, voice and participation and economic empowerment

2. To identify capacities of duty bearers (government, international organizations and UN agencies, international and national NGOS, grass-roots CSOs) in responding to the needs of the affected women, girls, boys and men; and in providing humanitarian services.

3. To understand the interaction between and among the affected people and the duty bearers.

\subsection{METHODOLOGY}

\section{Data collection}

The assessment utilized both qualitative and quantitative data collection methods. To generate the qualitative data, the study employed KIls and FGDs, plus a desk review of related literature.

\section{Profile of assessment areas and respondents}

The gender assessment was carried out in drought-affected areas in Wajir and Turkana; two Kenyan counties where Oxfam is particularly implementing an emergency response. Table 1 shows the population profile.

Table 1: Population profiles of Turkana and Wajir ${ }^{14}$

\begin{tabular}{|l|l|l|l|l|l|l|}
\hline County & $\begin{array}{l}\# \\
\text { Households }\end{array}$ & Area in sq.km & Population density & $\begin{array}{l}\text { Male } \\
\text { population }\end{array}$ & $\begin{array}{l}\text { Female } \\
\text { population }\end{array}$ & Total population \\
\hline Turkana & 123,191 & 1,520 & 562.8 & 445,069 & 410,330 & 855,399 \\
\hline Wajir & 88,574 & 815 & 812.2 & 363,766 & 298,175 & 661,941 \\
\hline Kenya & $8,767,104$ & 96,252 & 401.1 & $19,192,458$ & $19,417,639$ & $38,610,097$ \\
\hline
\end{tabular}

As shown in Table 2, the assessment covers five villages in Wajir and six villages in Turkana where Oxfam (through partners) is implementing an emergency CTP. 
Table 2: Profile of assessment areas

\begin{tabular}{|c|c|c|c|c|c|}
\hline \multicolumn{3}{|l|}{ WAJIR } & \multicolumn{3}{|l|}{ TURKANA } \\
\hline Village & $\begin{array}{l}\text { Sub- } \\
\text { county }\end{array}$ & Traits & Village & $\begin{array}{l}\text { Sub- } \\
\text { county }\end{array}$ & Traits \\
\hline Dambas & Tarbaj & $\begin{array}{l}\text { Rural, interior, many } \\
\text { pastoralists }\end{array}$ & $\begin{array}{l}\text { Maendeleo } \\
\text { (Kalokol) }\end{array}$ & $\begin{array}{l}\text { Turkana } \\
\text { Central }\end{array}$ & Peri-urban, with fishing \\
\hline Haragal & Tarbaj & $\begin{array}{l}\text { Rural, interior, many } \\
\text { pastoralists }\end{array}$ & $\begin{array}{l}\text { Locherekaal } \\
\text { (Lokichoggio) }\end{array}$ & $\begin{array}{l}\text { Turkana } \\
\text { West }\end{array}$ & $\begin{array}{l}\text { Rural, pastoral and agro- } \\
\text { pastoral }\end{array}$ \\
\hline Garakilo & $\begin{array}{l}\text { North } \\
\text { Wajir }\end{array}$ & $\begin{array}{l}\text { Rural, interior, many } \\
\text { pastoralists }\end{array}$ & $\begin{array}{l}\text { Napetet } \\
\text { (Lodwar) }\end{array}$ & $\begin{array}{l}\text { Turkana } \\
\text { Central }\end{array}$ & $\begin{array}{l}\text { Peri-urban; agro- } \\
\text { pastoral, trading }\end{array}$ \\
\hline Wajirbor & East Wajir & $\begin{array}{l}\text { Combination of rural } \\
\text { and peri-urban }\end{array}$ & $\begin{array}{l}\text { Natiir-Kenyaoil } \\
\text { (Keliye) }\end{array}$ & $\begin{array}{l}\text { Turkana } \\
\text { Central }\end{array}$ & Rural, fishing \\
\hline Dasheg & East Wajir & $\begin{array}{l}\text { Rural, many } \\
\text { pastoralists, few petty } \\
\text { traders }\end{array}$ & $\begin{array}{l}\text { Nayenae- } \\
\text { Angikalalio } \\
\text { (Lodwar) } \\
\text { Pokotom (Kakuma) }\end{array}$ & $\begin{array}{l}\text { Turkana } \\
\text { Central } \\
\text { Turkana } \\
\text { West }\end{array}$ & $\begin{array}{l}\text { Rural, pastoral } \\
\text { Rural, agro-pastoral }\end{array}$ \\
\hline
\end{tabular}

Figure 1 shows the gender profile of the KII, FGD and household survey respondents. KIls included 12 community leaders at the village level (four women and eight men); and 19 representatives of different sectors at county level (10 women and nine men), which included government staff, international NGOs including Oxfam, national NGOs, and one person from UNHCR. Observations were also noted in the seven villages. A total of 22 FGDs were held in villages; 11 men-only FGDs and 11 women-only FGDs. The assessment also employed quantitative data through a digital-based survey of 178 households in the 11 villages. Respondents included 119 women and 59 men.

\section{Figure 1: Gender profile of respondents}

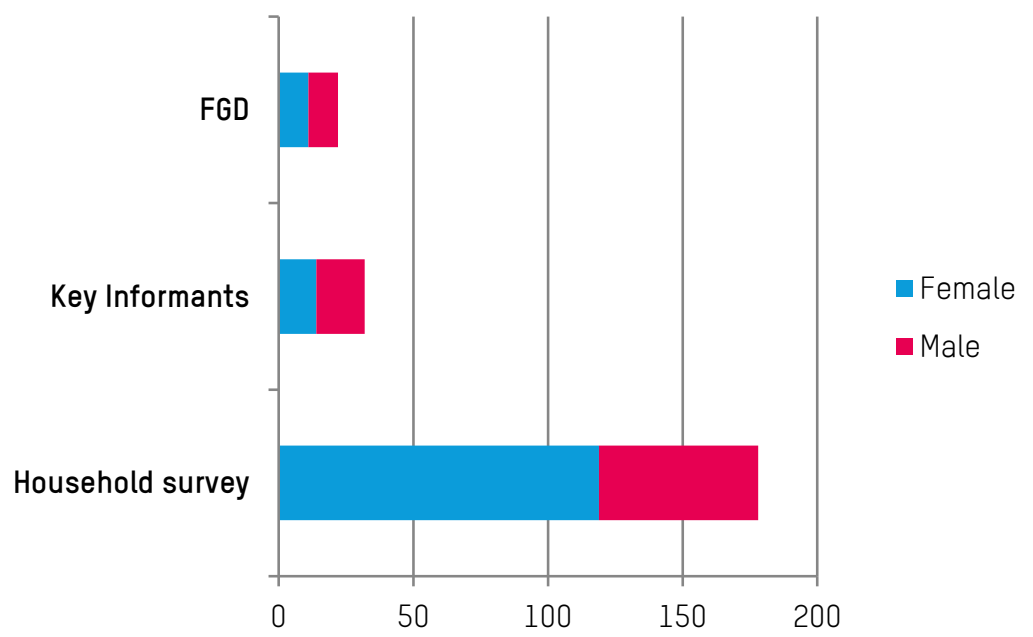


Table 3: Profile of household survey respondents

\begin{tabular}{|c|c|c|c|c|c|c|c|}
\hline & & \multicolumn{2}{|c|}{ Wajir } & \multicolumn{2}{|c|}{ Turkana } & \multicolumn{2}{|c|}{ Combined } \\
\hline & & No. & $\%$ & No. & $\%$ & No. & $\%$ \\
\hline \multirow[t]{4}{*}{ Age } & $14-18$ years old & 0 & $0 \%$ & 4 & $4 \%$ & 4 & $2 \%$ \\
\hline & 19-59 years old & 71 & $88 \%$ & 80 & $82 \%$ & 151 & $85 \%$ \\
\hline & 60 years old and above & 10 & $12 \%$ & 13 & $13 \%$ & 23 & $13 \%$ \\
\hline & Total & 81 & $100 \%$ & 97 & $100 \%$ & 178 & $100 \%$ \\
\hline \multirow[t]{3}{*}{ Sex } & Male & 26 & $32 \%$ & 33 & $34 \%$ & 59 & $33 \%$ \\
\hline & Female & 55 & $68 \%$ & 64 & $66 \%$ & 119 & $67 \%$ \\
\hline & Total & 81 & $100 \%$ & 97 & $100 \%$ & 178 & $100 \%$ \\
\hline \multirow{7}{*}{$\begin{array}{l}\text { Civil status/ } \\
\text { unions }\end{array}$} & Single & 1 & $1 \%$ & 6 & $6 \%$ & 7 & $4 \%$ \\
\hline & Monogamous married & 33 & $41 \%$ & 36 & $37 \%$ & 69 & $39 \%$ \\
\hline & Polygamous married & 43 & $53 \%$ & 44 & $45 \%$ & 87 & $49 \%$ \\
\hline & Widowed & 3 & $4 \%$ & 8 & $8 \%$ & 11 & $6 \%$ \\
\hline & Divorced & 1 & $1 \%$ & 1 & $1 \%$ & 2 & $1 \%$ \\
\hline & Separated / abandoned & 0 & $0 \%$ & 2 & $2 \%$ & 2 & $1 \%$ \\
\hline & Total & 81 & $100 \%$ & 97 & $100 \%$ & 178 & $100 \%$ \\
\hline \multirow{9}{*}{$\begin{array}{l}\text { Household } \\
\text { members }\end{array}$} & Boys below five years old & 112 & $21 \%$ & 91 & $14 \%$ & 203 & $17 \%$ \\
\hline & Girls below five years old & 88 & $16 \%$ & 64 & $10 \%$ & 152 & $13 \%$ \\
\hline & Boys $5-9$ yrs & 82 & $15 \%$ & 75 & $12 \%$ & 157 & $13 \%$ \\
\hline & Girls 5-9 yrs & 84 & $16 \%$ & 76 & $12 \%$ & 160 & $14 \%$ \\
\hline & Boys $10-17$ yrs & 62 & $12 \%$ & 76 & $12 \%$ & 138 & $12 \%$ \\
\hline & Girls 10-17 yrs & 42 & $8 \%$ & 58 & $9 \%$ & 100 & $8 \%$ \\
\hline & Elderly men & 31 & $6 \%$ & 28 & $4 \%$ & 59 & $5 \%$ \\
\hline & Elderly women & 35 & $7 \%$ & 179 & $28 \%$ & 214 & $18 \%$ \\
\hline & Total & 536 & $100 \%$ & 647 & $100 \%$ & 1183 & $100 \%$ \\
\hline
\end{tabular}

- Respondents were mostly females in the 18-49 age group, either in polygamous or monogamous marriage.

- Female-headed households are where pastoralist husbands are absent. In Wajir County, respondent households belonging to vulnerable age groups (below 5-17 years old, and the elderly) had more male members; while in Turkana there were more females.

- In both counties, 47 per cent of households (84 households) had pregnant or breast-feeding members and 22 per cent of households (40 households) had disabled or chronically ill members. 


\section{FINDINGS AND DISCUSSION}

\subsection{GENDERED VULNERABILITY ANALYSIS}

\subsubsection{Changing gender roles and responsibilities}

Gender determines the different roles that men and women play, as well as the power relations in the household and community. These roles and relations are often rigid in the pastoral communities. 'Both men and women have vital roles in the continuation and adaptation of pastoral systems. Women play a central role as livestock keepers, natural resource managers, income generators, and service providers - tasks which are influenced by gendered norms, values and relations. However, in spite of women's contribution to pastoral life, they have only limited access to, and control over, key productive resources such as livestock and land. They also have limited access to healthcare, education, family planning, and reproductive health. Moreover, the fundamental role of pastoral women in agriculture and livestock production has been systematically ignored and undervalued.' 15

The roles of women and men are very similar in Turkana and Wajir. Small differences can be attributed to the influence of Islam, which is the dominant religion in Wajir. The information in Table 4 below presents the traditional (pre-drought) roles of women and men. 
Table 4: Gender role patterns

\begin{tabular}{|c|c|c|c|c|}
\hline $\begin{array}{l}\text { Shared } \\
\text { Women-dominated } \\
\text { Men-dominated } \\
\text { Different in Wajir and Turkana }\end{array}$ & \multicolumn{2}{|l|}{ WAJIR } & \multicolumn{2}{|c|}{ TURKANA } \\
\hline Productive activity & women & men & women & men \\
\hline Migrate with livestock and search for pastures & & $x$ & & $x$ \\
\hline Keeping cattle/camels & $x$ & $x$ & $x$ & $x$ \\
\hline Selling cattle/camels & & $x$ & & $x$ \\
\hline Slaughtering cattle/camels & & $x$ & & $x$ \\
\hline Keeping goat/sheep & $\mathrm{x}$ & $x$ & $x$ & $x$ \\
\hline Selling goat/sheep & & $x$ & & $x$ \\
\hline Slaughtering goat/sheep & & $x$ & $x$ & \\
\hline Traditional milk processing and selling product & $\mathrm{x}$ & & $\mathrm{x}$ & \\
\hline Making and selling handicrafts & & $x$ & $x$ & \\
\hline Land preparation for farming & & $x$ & $x$ & \\
\hline Sowing and weeding & & $x$ & $x$ & \\
\hline Harvesting & & $x$ & $x$ & \\
\hline Petty trade (fruits, veg, oil) & $x$ & & $x$ & \\
\hline Fodder production & & $x$ & & $x$ \\
\hline Casual paid labour & & $x$ & & $\mathrm{x}$ \\
\hline Charcoal production & & $x$ & $x$ & \\
\hline Reproductive activity & & & & \\
\hline Childcare & $x$ & & $x$ & \\
\hline Care of elderly and sick & $x$ & & $x$ & \\
\hline Cooking meals & $\mathrm{x}$ & & $x$ & \\
\hline Fetching water & $x$ & & $x$ & \\
\hline Firewood collection & $x$ & & $x$ & \\
\hline Construction of house/temporary shelter & $x$ & & $x$ & \\
\hline Meat preservation & $x$ & & $x$ & \\
\hline Housework & $x$ & & $x$ & \\
\hline Washing clothes & $x$ & & $x$ & \\
\hline Community activity & & & & \\
\hline Construction of communal house & & $x$ & $x$ & \\
\hline Maintenance of water points & & $x$ & & $x$ \\
\hline Construction of roads & & $x$ & & $x$ \\
\hline Participating in wedding & & $x$ & & $x$ \\
\hline Going to mosque/church & & $x$ & $x$ & \\
\hline Negotiating (conflict resolution) & & $x$ & & $x$ \\
\hline Grazing land protection & & $x$ & & $x$ \\
\hline Mourning ceremony & & $x$ & $x$ & \\
\hline Participating in relief activities & $\mathrm{x}$ & & $x$ & \\
\hline
\end{tabular}


Table 4 shows that in Wajir, out of the 16 productive activities, only two are clearly dominated by women: processing and selling of milk products, and petty trading. In Turkana women perform more productive roles than in Wajir, such as slaughtering small livestock, ${ }^{16}$ handicrafts, and charcoal production. Farming activities (land preparation, sowing, weeding and harvesting) are dominated by men in Wajir but by women in Turkana. Women and men share the roles when it comes to keeping livestock.

Meanwhile, reproductive activities are dominantly performed by women in both counties. For community activities, the majority are dominated by men, especially in Wajir. Interestingly, the construction of houses as family shelter (a reproductive activity) is a female role. But if it is a structure with a community purpose, it is done by men in Wajir. Going to church or mosque and attending mourning ceremonies are male roles in Wajir and female roles in Turkana. Lastly, in both counties, participating in relief activities is a women's role.

\section{Changing gender roles}

It has been said that 'during times of severe drought households and communities adapt their activities, roles and responsibilities in order to survive. Difficult decisions need to be made concerning whether the family should split or not, and how remaining resources should be distributed. Both men and women have their role to play and will be affected by the decisions made by the other'. ${ }^{17}$ This drought has opened opportunities for changing gender roles, which are evident to a certain extent in some examples from Turkana and Wajir.

More women in Turkana expressed the opinion that changes in gender roles were occurring. This was not so apparent in Wajir. According to one female FGD participant in Nayanae Angikalalio (Lodwar, Turkana Central), everyone worked according to their strength rather than being restricted by their gender. Because of the great need to survive and alleviate suffering caused by the drought, instead of performing traditional gender roles, people were having to perform non-traditional roles. Men in Turkana and Wajir affirmed that some roles were explicitly changing because of the drought. One male FGD participant from Napetet (Lodwar, Turkana Central) said: 'Yes, we have learned that by accepting to exchange roles we are likely to help each other properly.'

\section{Examples of changing gender roles include:}

1. Women are more involved in productive activities.

- Women have become main family breadwinners. Hence, their productive activities have expanded as they are the main provider for their families. This is evident in Locherekaal (Lokichogio, Turkana West).

- Women are now more involved in casual labour. This is evident in Napetet (Lodwar Turkana Central).

2. Men are more open to reproductive roles (more so in Turkana than Wajir).

- Collecting firewood to sell, and charcoal burning, used to be women's tasks but now men are doing them.

- Men are also helping with, if not doing, domestic work such as cooking and fetching water.

- Men also are now taking care of children or nursing ill family members while women leave the home for many hours to collect water or to look for food or sell charcoal.

3. Decisions to sell animals are now being made jointly and not just by men, in both areas.

4. Women are also increasing their community roles because of opportunities given by aid agencies (e.g. membership of relief or water management committees). This is more limited for Wajir, if the activity requires movement to distant places.

5. Children are often helping their parents, usually supporting the roles ascribed to their respective genders. Girls help their mothers a lot or perform their own assigned gender roles. Likewise, boys help their fathers and perform their gender roles.

\subsubsection{Number of working hours}

When all work - paid and unpaid - is accounted for, women work longer hours than men. This is according to the UN report The World's Women 2015, ${ }^{18}$ which found women spend an average of 30 minutes a day 
longer than men on paid and unpaid work in developed countries, and 50 minutes longer in developing countries. ${ }^{19}$ The figures from the assessment for Turkana and Wajir are much higher than the global average. As seen in Table 5 below, women work an average of 17.6 hrs daily, while men engage in 15.5 hrs work a day.

Table 5: Average daily hours of work (paid and unpaid)

\begin{tabular}{|l|l|l|l|}
\hline & Turkana & Wajir & Both \\
\hline Women & 17 & 18.4 & 17.6 \\
\hline Men & 15.5 & 15.6 & 15.5 \\
\hline Difference & 1.5 & 2.8 & 2.07 \\
\hline
\end{tabular}

'Unpaid care work lalso called household work, domestic labour, or family work) refers to the provision of services for family and community members outside of the market, where concern for the well-being of the care recipients is likely to affect the quality of the service provided (Folbre 2006).'20 Women in both areas have been doing a lot of unpaid care work. Men are using their time for productive work, mainly herding. However, for those who lost animals, idle time among men has increased. On how to reduce the burden of too much reproductive care work, some of the male and female respondents suggested the following:

1. Better and safe access to water, e.g. for irrigation purposes, so that women can farm instead of doing charcoal burning or collecting gravel, and for domestic use, to shorten the long distances they frequently walk to collect water. There should be support for transporting more water by bicycle or motorbike, and for providing more water storage containers such as jerry cans.

2. Increase food supply, relief or cash assistance.

3. Affordable and accessible health services, free maternity services, and provision of sanitary towels/pads.

4. Support for livelihoods such as re-stocking and providing animal feed.

\subsubsection{Access to and control over productive resources}

Land, house/dwelling and livestock (sheep or goats) are assets owned jointly by husband and wife respondents from Wajir and Turkana. Although 53 per cent of them do have their own mobile phones, almost half ( 45 per cent) still do not have one. Meanwhile, 2 percent owns them jointly. All other assets deemed relevant for livelihoods, such as ownership of other livestock like donkeys, mules or camels; farming equipment; jewellery or gems; and household entertainment equipment are generally not owned by the respondents. See Table 6 for more details. 
Table 6: Household ownership of assets, by type and ownership status

\begin{tabular}{|c|c|c|c|c|}
\hline \multirow{2}{*}{ Asset type } & \multirow{2}{*}{ Ownership status } & Wajir & Turkana & Combined \\
\hline & & $\%$ & $\%$ & $\%$ \\
\hline \multirow{4}{*}{ Land } & Does not own & $30 \%$ & $39 \%$ & $35 \%$ \\
\hline & Owns jointly & $44 \%$ & $39 \%$ & $42 \%$ \\
\hline & Owns alone & $26 \%$ & $22 \%$ & $24 \%$ \\
\hline & Total & $100 \%$ & $100 \%$ & $100 \%$ \\
\hline \multirow{4}{*}{ House (dwelling) you are living in } & Does not own & $37 \%$ & $29 \%$ & $33 \%$ \\
\hline & Owns jointly & $37 \%$ & $48 \%$ & $43 \%$ \\
\hline & Owns alone & $26 \%$ & $23 \%$ & $24 \%$ \\
\hline & Total & $100 \%$ & $100 \%$ & $100 \%$ \\
\hline \multirow{4}{*}{ Livestock: donkeys/mules } & Does not own & $56 \%$ & $84 \%$ & $71 \%$ \\
\hline & Owns jointly & $28 \%$ & $11 \%$ & $19 \%$ \\
\hline & Owns alone & $16 \%$ & $5 \%$ & $10 \%$ \\
\hline & Total & $100 \%$ & $100 \%$ & $100 \%$ \\
\hline \multirow{4}{*}{ Livestock: sheep/goats } & Does not own & $17 \%$ & $44 \%$ & $32 \%$ \\
\hline & Owns jointly & $64 \%$ & $40 \%$ & $51 \%$ \\
\hline & Owns alone & $19 \%$ & $15 \%$ & $17 \%$ \\
\hline & Total & $100 \%$ & $100 \%$ & $100 \%$ \\
\hline \multirow{4}{*}{ Livestock: camels } & Does not own & $75 \%$ & $81 \%$ & $79 \%$ \\
\hline & Owns jointly & $16 \%$ & $9 \%$ & $12 \%$ \\
\hline & Owns alone & $9 \%$ & $9 \%$ & $9 \%$ \\
\hline & Total & $100 \%$ & $100 \%$ & $100 \%$ \\
\hline \multirow{4}{*}{ Farming equipment } & Does not own & $96 \%$ & $89 \%$ & $92 \%$ \\
\hline & Owns jointly & $2 \%$ & $7 \%$ & $5 \%$ \\
\hline & Owns alone & $1 \%$ & $4 \%$ & $3 \%$ \\
\hline & Total & $100 \%$ & $100 \%$ & $100 \%$ \\
\hline \multirow{4}{*}{ Jewellery or gems } & Does not own & $100 \%$ & $74 \%$ & $86 \%$ \\
\hline & Owns jointly & $0 \%$ & $0 \%$ & $0 \%$ \\
\hline & Owns alone & $0 \%$ & $26 \%$ & $14 \%$ \\
\hline & Total & $100 \%$ & $100 \%$ & $100 \%$ \\
\hline \multirow{4}{*}{$\begin{array}{l}\text { Major household equipment like } \\
\text { TV, radio }\end{array}$} & Does not own & $86 \%$ & $92 \%$ & $89 \%$ \\
\hline & Owns jointly & $1 \%$ & $8 \%$ & $5 \%$ \\
\hline & Owns alone & $12 \%$ & $0 \%$ & $6 \%$ \\
\hline & Total & $100 \%$ & $100 \%$ & $100 \%$ \\
\hline \multirow{4}{*}{ Mobile phone } & Does not own & $37 \%$ & $52 \%$ & $45 \%$ \\
\hline & Owns jointly & $2 \%$ & $2 \%$ & $2 \%$ \\
\hline & Owns alone & $60 \%$ & $46 \%$ & $53 \%$ \\
\hline & Total & $100 \%$ & $100 \%$ & $100 \%$ \\
\hline \multirow{4}{*}{ Any other property } & Does not own & $80 \%$ & $91 \%$ & $86 \%$ \\
\hline & Owns jointly & $9 \%$ & $3 \%$ & $6 \%$ \\
\hline & Owns alone & $11 \%$ & $6 \%$ & $8 \%$ \\
\hline & Total & $100 \%$ & $100 \%$ & $100 \%$ \\
\hline
\end{tabular}

\subsubsection{Decision making and participation in households}

The majority of respondents agreed that the man/husband has the most power/status/privilege over the woman/wife within the household. The man is the head of the family or household. They believed that a man 'owns' the woman and children by virtue of paying dowry. Male FGD participants in Turkana argued that the Bible says man was created first and society has given men certain powers over women: men own and control resources, including animals, and command a lot of respect. They argued that their culture dictated that women have not been given any privilege or position of power: women only supplement men in everything they do. One male participant, however, said that with the drought, woman had power because 
of the aid they were receiving from all agencies. Another participant expressed that women no longer listened to men.

People may leave their community and go to other places for work, or to do other things for their lives. Men can make decisions about moving on their own, and are not required to consult or ask permission from anyone. This is not the case for women especially in Wajir, as they are required to ask the approval of their spouse (or father, if unmarried). In most FGDs, participants expressed that women are regarded as vulnerable, so it is better for them to stay at home if their spouse moves to find new pastures, for example.

Comparing women and men, FGD participants expressed that it is easier for men to make independent decisions than their wives. Men are accorded privilege; they occupy a higher position in society, and are head of the family. Men are perceived to be always right and must be taken seriously. Men also control most of the family's resources. As one female FGD participant expressed, men are their own boss. Another female participant in Wajir pointed out that in some areas, men usually consult female household members. But this is limited to the reproductive sphere, e.g. issues concerning children.

In most FGDs, both women and men expressed that women are inferior and can easily make wrong decisions. If a woman needs to make decisions, she can do so after discussing with a man (the husband or fatherl and the man must agree with her and support the decision. In Turkana, it was noted that boys cannot make decisions without consulting elder men, as it is considered rude. On the other hand, if girls make decisions without the approval of elders (or disobey their decisions), it is considered an abomination.

\section{Changing patterns in decision making at household level}

During FGDs, men in Turkana expressed that in recent years, decision making at household level was changing. In Wajir, some of them explained how the drought had been challenging the traditional set-up. They expressed that they had to travel to different places to seek opportunities to earn a living. Women and men were being forced to make new arrangements to survive. The difficulty of finding pastures elsewhere, the loss of livestock (and they could not re-stock), the security risks and other challenges brought by more and more frequent and long droughts are forcing people to shift from a nomadic to a more sedentary life. This has an impact on what and how decisions are made.

However, there is a long way to go for women to be really heard and be systematically part of decision making processes. The authority structure of pastoralist communities has 'distinct value systems which are the organizing principles of their social fabric. Most arid lands communities are patrilineal, and older male community members dominate in issues such as property, livelihood, and political decision making. The family, lineage or clan is considered a central unit in the social cosmos, while the individual is less significant. The family includes ascendants and descendants, mostly of the male line. The family, and particularly its male members, also constitutes the core unit that is held responsible if a member is accused of breaking communal rules. The family units, therefore, usually constitute the main parties of a conflict, since they are responsible for the actions of their kin. When women want to air their grievances, the male head of the household, be it the husband or father, is the main addressee. If the grievance or conflict is in relation to domestic life, a woman has the option of taking it up with her husband's family, or she can address her own family. The male head of a family decides whether cases should be taken up with the head of the opponent family, whether they should be brought before elders to help identify a solution, or whether they should be taken to the formal court'. ${ }^{21}$

\subsubsection{Decision making and participation at community level}

Just like in their homes, men have power, privilege and high status within the community. Among them, elder men have the greatest power. The very high regard and respect to elder men is evident both in Turkana and Wajir. The words of these elders should not be questioned. They are wise and view life from many angles. Men occupy leadership roles in the family, in the village as well as in the church or mosque. Men are also regarded as protectors of their land. Women on the other hand are inferior, especially in that their knowledge and experience are limited.
'Ayong eusit aberu meere ngesi keusit ayong.'

'I am the one who married my wife and it is not her who married me.'

Male FGD participant, Pokotom Kakuma, Turkana West 
In Turkana, women can participate openly and freely in community discussions. They are also allowed to attend (but not necessarily to speak out at) political rallies that are often supported by politicians. Women in Wajir are more constrained to openly attend community discussions.

While they can participate in community forums, it should be noted that in most cases, women's issues are not on the agenda. If there are meetings that they frequently attend, those meetings usually discuss issues affecting them and their children. However, men still have the final say on most issues, including sensitive issues like rape cases, and what actions should be taken or not taken.

\section{Changing set-up in the community}

In Turkana, male FGD participants acknowledged that NGOs (Oxfam was specifically named) and the church have been helping women to actively participate and raise various issues such as: political participation; children's education; access to business skills, training or loans; and utilization of community resources (e.g. which trees to burn for charcoal making). Women are also being given the chance to chair meetings and be politically represented.

Women are often allowed to participate in emergency response management-related activities, even joining committees to support relief operations (e.g. water point management or food distribution). Women are usually contacted by aid agencies and often targeted as beneficiaries as well as participants to different activities. In Wajir, government programmes target women. Some NGOs also organize women or ensure women are represented in informal committees, e.g. the Lokichogio water users' association. Women benefit from relief aid, training and exposure. There are also self-organized groups that come together for a shared activity such as charcoal burning and selling. Women get support from participating in these informal groups or at least from the increased solidarity among women.

However, in most cases, women will shy off in the presence of men. So even if they sit as representatives, they will choose to be passive in the discussions and allow the men to discuss and make decisions. There are also topics that women will not touch, like sex, property-sharing and ownership.

While women appreciate the opportunities provided by aid agencies, they also say that they are not substantially consulted on these activities, including on the kind of aid that is given. Although consultation is done with communities and beneficiaries, some agencies have fixed areas of intervention and plan activities accordingly. Women have accomplished a lot of things but sometimes they are not properly recognized, and men often get the credit.

When women encounter problems, they report to their families, who may forward the case to the village elders in Turkana or the religious leaders in Wajir. Most of the time, people rely on the leader la chief or an imam) to act. Actions are taken in community assemblies. If issues pertain to criminal acts, the leaders report to formal institutions like the police or a judicial court. However, it should be noted that all these discussions and decision making are done by men. The woman (complainant) is not usually allowed to participate. The final decisions usually favour the community or families involved, but not necessarily the woman (victim). Justice is served through payment, which usually comes in the form of livestock.

Women would have some advantage if the council of elders had women representatives ${ }^{22}$ because they would listen to fellow women. Some women complain and seek assistance from NGOs and the church. They get support such as arbitration and legal assistance if applicable. There are very few WROs in these areas. Turkana Women Advocacy and Development Organization (TWADO) and Turkana Women Conference Centre (TWCC) are known in Turkana but no equivalents were named in Wajir. Some NGOs ${ }^{23}$ assist women to access legal services, children protection and childcare in the event of separation. Women also access information on how to report cases of rape, on property inheritance, treatment of AIDS and business. In Kalokol (Turkana), TWCC has organized strong women empowerment groups that support women and follow through their cases. Men appreciate the support the groups are giving. Being organized has benefits, but most of these informal groups are not well resourced. They struggle to sustain their activities.

Women also report incidents directly to the chief because they know they will not be supported by the men in their family. These are usually sensitive issues like sexual violence, which as mentioned, are often settled by pay-offs (e.g. 20 goats). It was shared in one FGD discussion that men would often prefer to keep the issues among those involved and be paid. Cases were mentioned where men would even bribe the chief 
to ignore the complaints. There was a case in Wajir where the father of a girl-child rape survivor denied the incident. The Ministry of Gender pursued the case. But the father asked another daughter to replace her sister for the medical check-up, so it turned up negative with no evidence of rape.

Negotiation is easier for men than women, who are in a more disadvantaged position. Men are already in positions of power both at family and community levels, while women are not.

Women don't have any control over resources or any leverage. They also lack experience, confidence and negotiation skills. One female FGD participant expressed: 'A woman is expected to be behaving acceptably otherwise she will not be listened to, while a man can speak and be listened to just by the mere fact that he is a man.' Furthermore, depending on the issue, women are afraid to speak out of fear. They can be beaten by their husbands or even chased out of their homes.

One way for women to be heard is if they occupy more formal political spaces. Women who engage in politics use their leadership position to advance and/or provide desired services or goods to other women. According to Jully Adome, Acting Director of TWCC, they have invested many years in creating awareness about women's political rights and trained many women leaders. A few of their graduates have become village chiefs.

\subsection{GENDER-DIFFERENTIATED IMPACT ANALYSIS}

\subsubsection{Food security}

Respondents reported that the elderly (30 per cent), women (24 per cent), infants (18 per cent) and pregnant/lactating women are the most affected by food insecurity. The elderly are perceived to be suffering most in Turkana, and women in Wajir. In both areas, respondents said men are suffering less.

Table 7: Food-insecure groups

\begin{tabular}{|l|l|l|l|l|l|l|}
\hline \multirow{2}{*}{} & \multicolumn{2}{l}{ Wajir } & \multicolumn{2}{l|}{ Turkana } & \multicolumn{2}{l|}{ Combined } \\
\cline { 2 - 7 } & No. & $\%$ & No. & $\%$ & No. & $\%$ \\
\hline Elderly & 12 & $15 \%$ & 42 & $43 \%$ & 54 & $30 \%$ \\
\hline Women & 12 & $15 \%$ & 31 & $32 \%$ & 43 & $24 \%$ \\
\hline Infants & 24 & $30 \%$ & 8 & $8 \%$ & 32 & $18 \%$ \\
\hline Pregnant/breast-feeding women & 25 & $31 \%$ & 4 & $4 \%$ & 29 & $16 \%$ \\
\hline Disabled & 4 & $5 \%$ & 3 & $3 \%$ & 7 & $4 \%$ \\
\hline Men & 4 & $5 \%$ & 2 & $2 \%$ & 6 & $3 \%$ \\
\hline Particular ethnic or clan group & 0 & $0 \%$ & 6 & $6 \%$ & 6 & $3 \%$ \\
\hline Girls & 0 & $0 \%$ & 1 & $1 \%$ & 1 & $1 \%$ \\
\hline Boys & 0 & $0 \%$ & 0 & $0 \%$ & 0 & $0 \%$ \\
\hline Total & 81 & $100 \%$ & 97 & $100 \%$ & 178 & $100 \%$ \\
\hline
\end{tabular}

Eighty per cent further shared that food supply in homes was inadequate, as shown in Figure 2. This was caused by production loss ( 40 per cent) and food price increases (38 percent), as shown in Figure 3. 
Figure 2: Availability of food in the house

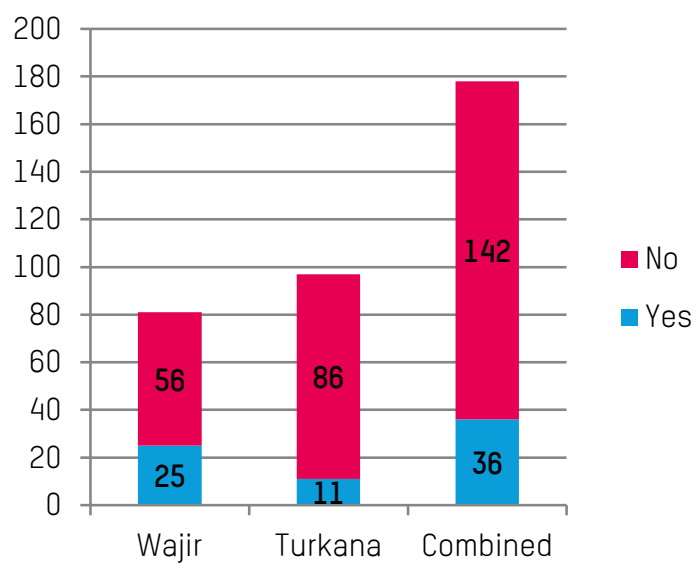

Figure 3: Reasons for lack of food availability

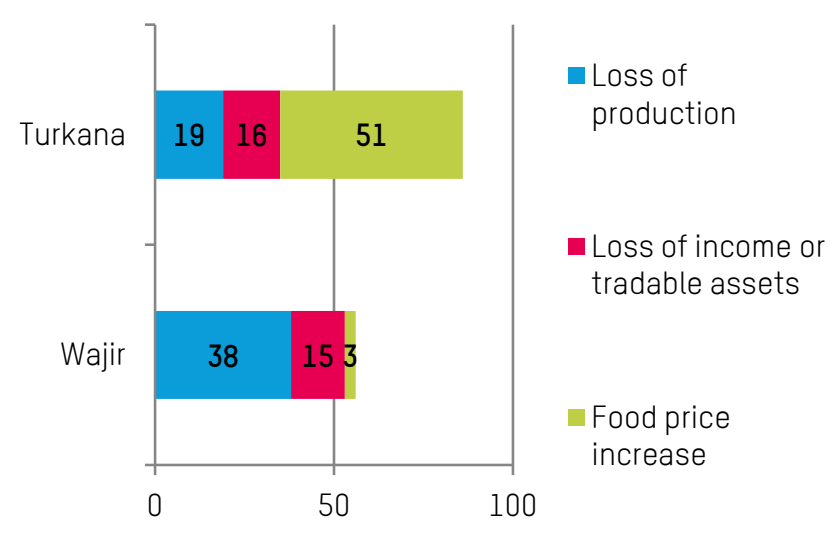

Children ( 48 per cent) and men (33 per cent) were considered household priorities for food intake, as shown in Figure 4. The elderly, women and infants were the lowest priorities. Pregnant/breast-feeding women and the disabled were not even mentioned, despite being members of significant numbers of respondent households. Men were the top priority in Wajir, but not in Turkana.

\section{Figure 4: Household prioritization for food intake}

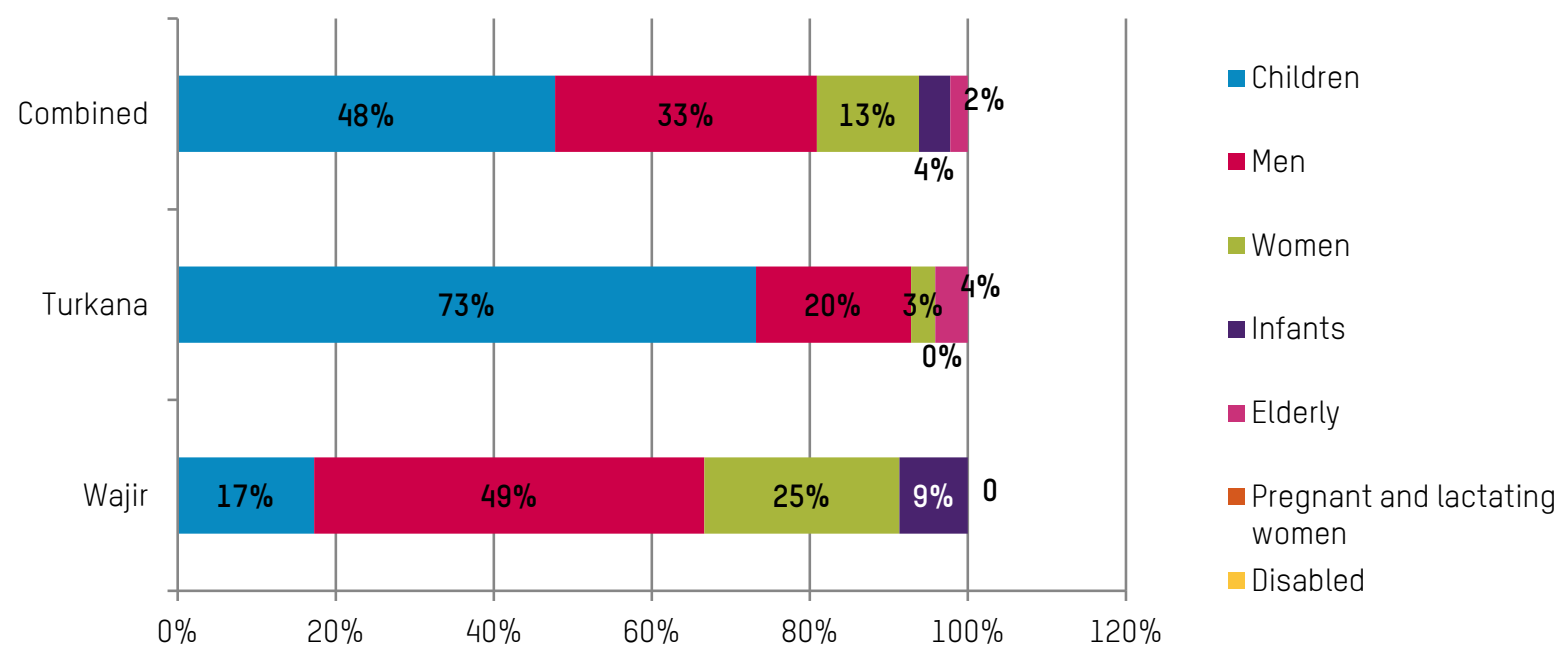

Figure 5 shows that 134 (75 per cent) of respondents reported not having access to food or cash transfer programming. And while 56 per cent said women/wives made decisions about the use of food aid (Figure 6), 44 per cent said men/husbands determined cash usage (Figure 7). 
Figure 5: Respondent access to food or cash transfer programme

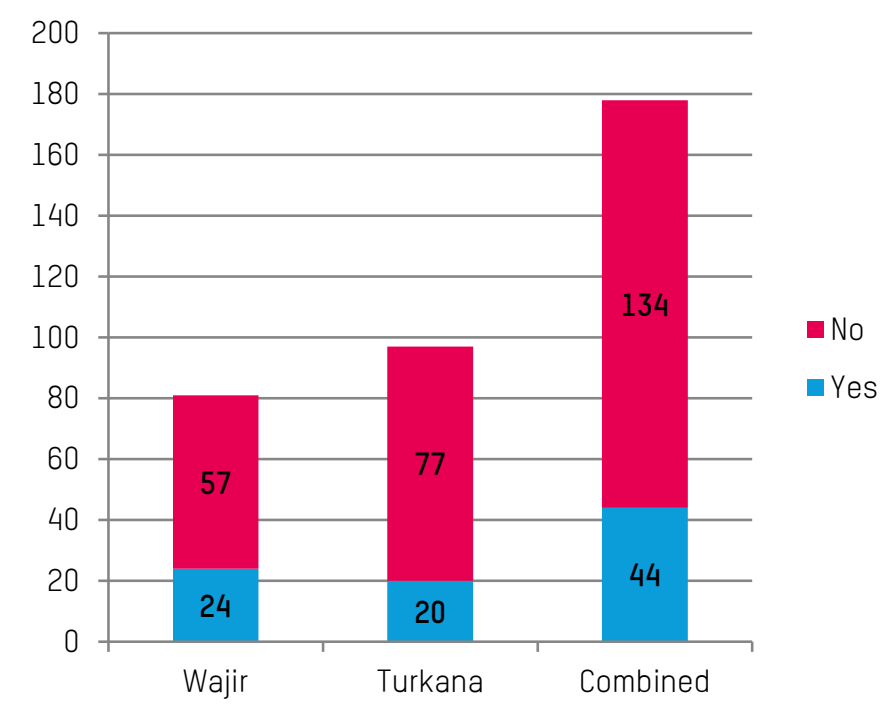

Figure 6: Who makes decisions on food aid usage?

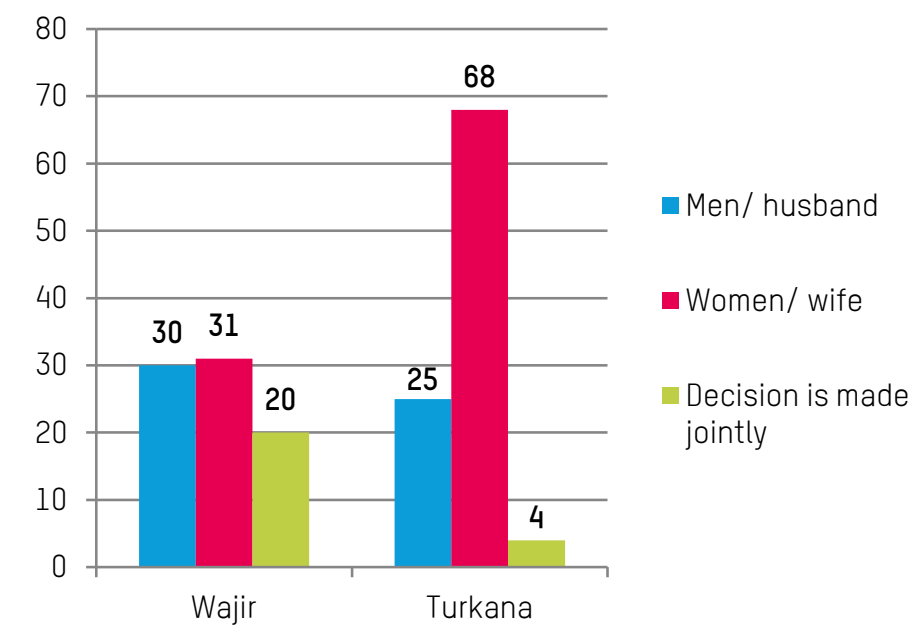

Figure 7: Who makes decisions on cash aid?

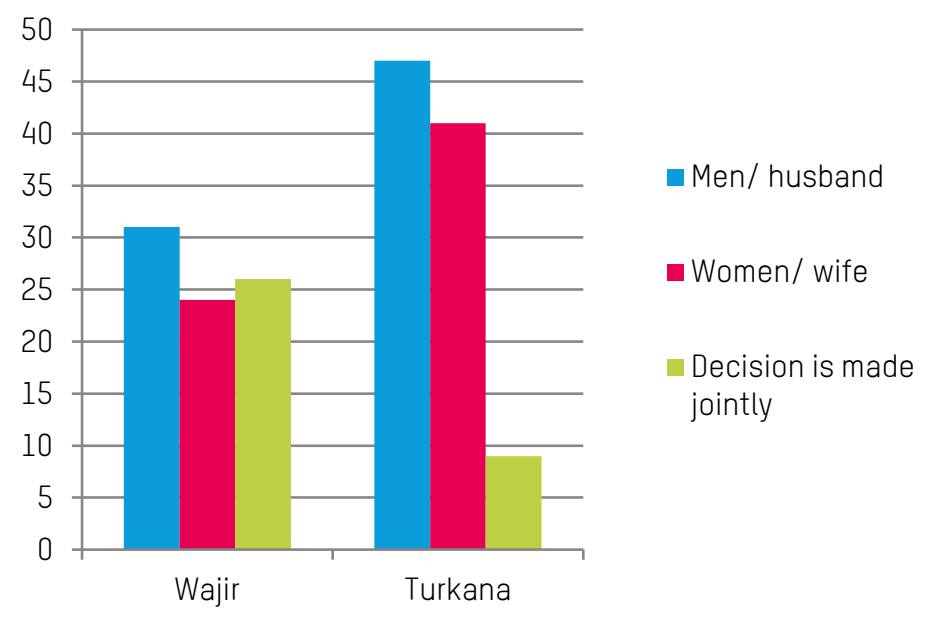




\subsubsection{Livelihoods, livelihood shifts and implications for men and women}

Pastoralism is traditionally the predominant livelihood in the two counties. Some families are still very nomadic and all move together. Other households are divided into nomadic and sedentary, whereby some of the members move while others remain in sedentary arrangements. Many are getting more engaged in petty businesses or paid labour. Wage earners still maintain their livestock, through relatives in remote villages who manage the herd. This diversification is apparent from the household survey, where most respondents ticked more than one source of livelihood.

\section{Table 8: Sources of income}

\begin{tabular}{|l|l|l|l|l|l|l|}
\hline & \multicolumn{3}{|l}{ Wajir } & Turkana & \multicolumn{2}{l|}{ Combined } \\
\cline { 2 - 7 } & No. & $\%$ & No. & $\%$ & No. & $\%$ \\
\hline Livestock & 78 & $30 \%$ & 33 & $24 \%$ & 111 & $28 \%$ \\
\hline Crop farming & 18 & $7 \%$ & 3 & $2 \%$ & 21 & $5 \%$ \\
\hline Both livestock and crop farming & 43 & $17 \%$ & 6 & $4 \%$ & 49 & $12 \%$ \\
\hline Petty trade & 61 & $24 \%$ & 35 & $25 \%$ & 96 & $24 \%$ \\
\hline Paid casual labour & 32 & $13 \%$ & 30 & $22 \%$ & 62 & $16 \%$ \\
\hline Others & 24 & $9 \%$ & 31 & $22 \%$ & 55 & $14 \%$ \\
\hline Total & 256 & $100 \%$ & 138 & $100 \%$ & 394 & $100 \%$ \\
\hline
\end{tabular}

With the drought, more and more people have diversified or even shifted from one type of livelihood to another. There is a big shift from livestock to other options. ${ }^{24}$ Table 9 shows the diversification of livelihoods before and during the drought among women and men in Turkana and Wajir. Women are engaging in more new activities than men. Another study said that it was 'reported that most of these livelihood diversification activities are practiced by women in Turkana'. ${ }^{25}$ Alcohol, gambling and prostitution are mentioned only in Turkana but not in Wajir. Fishing activity is in Turkana Lake. 
Table 9: Comparison of livelihoods before and during the drought

\begin{tabular}{|c|c|c|c|}
\hline \multicolumn{2}{|l|}{ LIVELIHOODS OF WOMEN } & \multicolumn{2}{|l|}{ LIVELIHOODS OF MEN } \\
\hline Before the drought & During the drought & Before the drought & During the drought \\
\hline $\begin{array}{ll}\text { - } & \text { Burning and selling } \\
\text { - } & \text { Livarcoal } \\
\text { (selling livestock or } & \text { animal produce) } \\
\text { - } & \text { Making and selling local } \\
\text { brew (alcohol) } \\
\text { - } \quad \text { Making handicrafts } \\
\text { - } \quad \text { Packing fish on } \\
\text { - } \quad \text { Pammission housemaids } \\
\text { - } \quad \text { Petty trade } \\
\text { - } \quad \text { Picking and selling wild } \\
\text { - } \quad \text { berries } \\
\text { - } \\
\text { - } \quad \text { Selling farm proding firewood } \\
\text { - } \quad \text { Selling gums } \\
\text { - } \quad \text { Selling rocks } \\
\quad \text { Weaving }\end{array}$ & 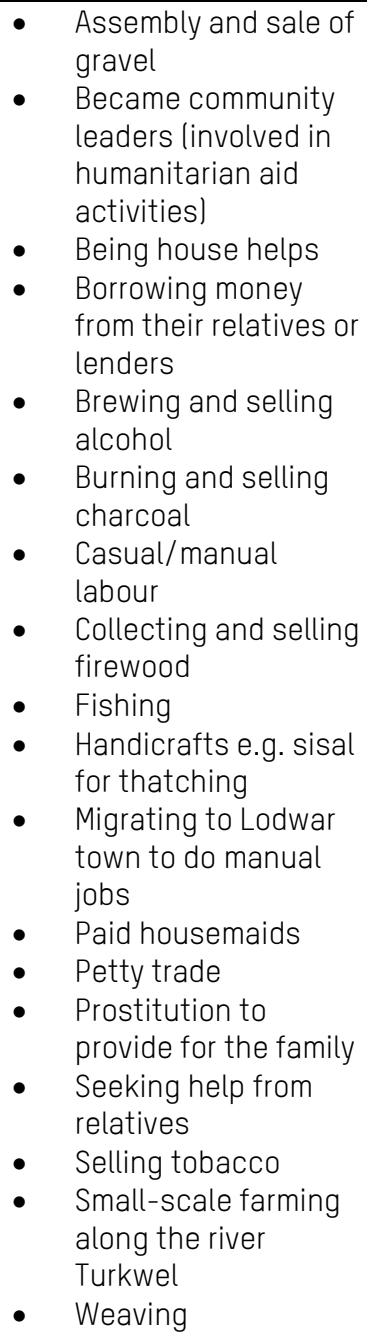 & $\begin{array}{l}\text { - Casual labour } \\
\text { - Boda-boda } \\
\text { (motorcycle) driver } \\
\text { - Construction of } \\
\text { - houses } \\
\text { - Fetching firewood } \\
\text { and selling } \\
\text { - Fishing } \\
\text { - Herding of animals } \\
\text { - } \text { and selling livestock } \\
\text { - Mason helpers in } \\
\text { building sites } \\
\text { - Mining lquarrying } \\
\text { rocks, some } \\
\text { minerals) } \\
\text { - Petty trade } \\
\text { - Selling gums } \\
\text { - Watchmen }\end{array}$ & 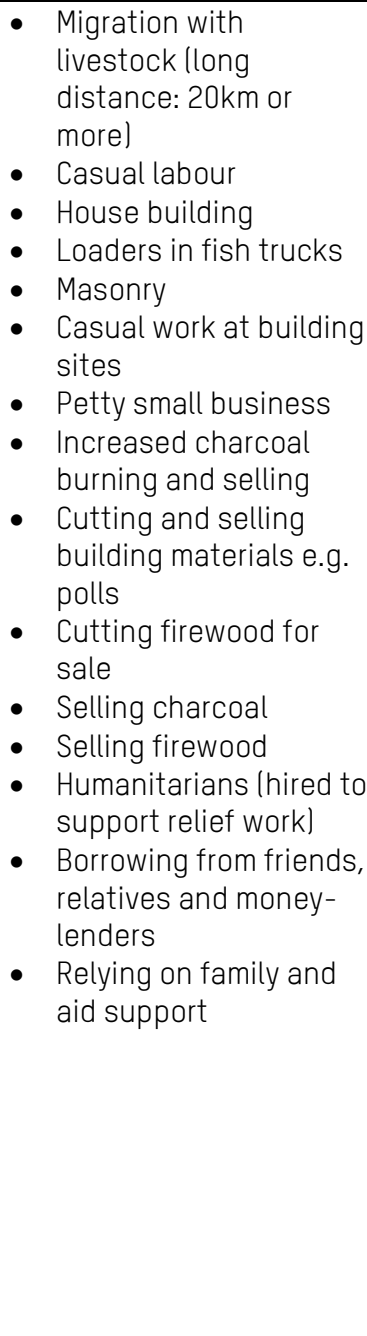 \\
\hline
\end{tabular}

The shifts in livelihoods, once superimposed on gender roles, cause different impacts on women and men. As men (including older boys) take care of bigger animals (cattle, camels), they ended up with nothing to do as the animals became ill and died, or were sold. There is stronger resistance to shift to new roles among men compared with women. Men are very selective about which reproductive roles to do. Meanwhile women add more hours (e.g. water collection) to domestic work while still taking care of any remaining animals. Options for casual labour and petty trading are often taken by women. Women tend to diversify as much as possible and engage in anything just to support the family.

Before the drought, many children were going to school, but have now mostly dropped out. As of March 2017, approximately 180,000 children dropped out of school due to the drought, a majority of them girls las they are responsible for domestic chores such as fetching water ${ }^{26}$ ) According to a March 2017 report by OCHA highlighting the impact of drought and conflict on women and girls, the drought has forced women to make very difficult decisions about whether their children can continue to attend school. ${ }^{27}$

Despite shifting to other livelihood streams and engaging in coping strategies, overall food needs and income are still not being secured. Income from casual labour is very low. People are losing whatever remaining assets and natural resources they have (e.g. the water in Lake Turkana has receded). Small businesses are barely surviving because customers have reduced purchasing power. Food prices and the cost of living have risen dramatically and so families have incurred more debts. Economic dependency on 
relatives has increased. Those in town are hosting many relatives, and have increased their dependents at least by 100 percent. Because hosts are often wage earners, they don't qualify for humanitarian aid. Overall, relief aid has diminished, especially from NGOs. These issues have resulted in more conflicts and security concerns, with increases in family conflicts and crime.

\subsubsection{Health, including reproductive health}

\section{Health}

Both women and men cited common illnesses which are usually associated with poverty, environment or being old, such as tuberculosis, pneumonia, malaria, arthritis and ulcers. Some expressed symptoms which have not yet been properly diagnosed, such as back pain, chest pain, frequent headaches, high blood pressure, hearing and visual impairment, and insomnia. Gender-specific reproductive health problems were also cited, such as cervical cancer for women. Men identified more reproductive issues, including prostrate problems and difficulty in urinating, as well as erectile dysfunction (especially among elderly men). They also said that boda-boda (motorcycle) drivers often suffered pain in their testicles. Both women and men mentioned the prevalence of sexually transmitted diseases, including HIV/AIDS.

In Turkana, all FGDs reported that stress was very high. They associated most of their medical symptoms with stress caused by the drought. Women said they were overworked. Some men complained that hard labour (like quarrying) was completely exhausting them. Men especially reported suffering from mental stress, as they were always worried about not being able to provide. There are men in Turkana (Kaolokol, Nayanae and Locherekaal) who have committed suicide due to the mental stress.

\section{Reproductive health}

As shown in Figure 8 below, 126 (71 per cent) of respondents reported that a health post or health extension worker was present in their community or area. Figure 9 indicates that only 53 per cent have access to reproductive health $(\mathrm{RH})$ services such as family planning, pre- and post-natal care and attended delivery. Figure 10 shows that these services are mainly offered by government health posts/centres or nearby clinics. Figure 11 shows that the other 47 per cent fail to access these services mainly because their partner/s do not allow or permit it (58 per cent), or for other reasons (29 per cent).

Figure 8: Presence of health posts/extension workers

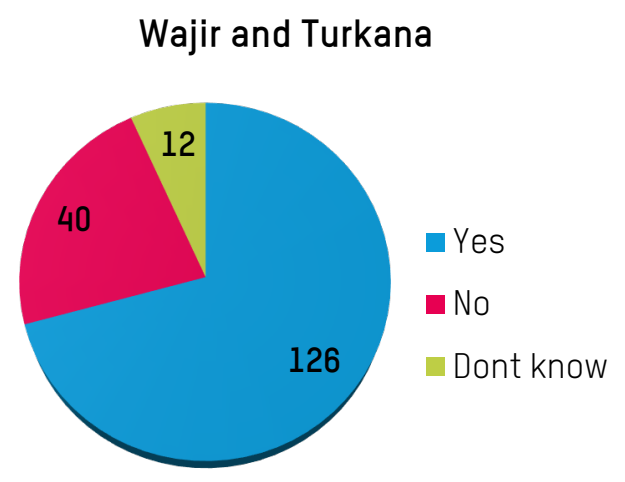

\section{Figure 9: Access to RH services}

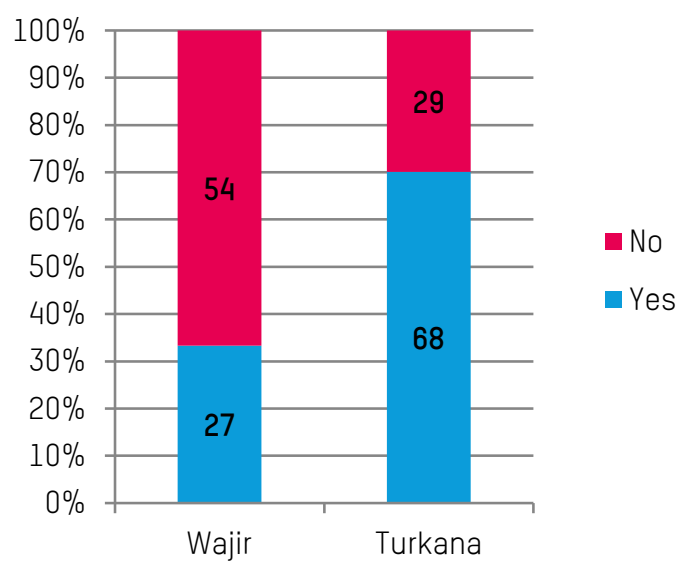




\section{Figure 10: $R H$ service providers}

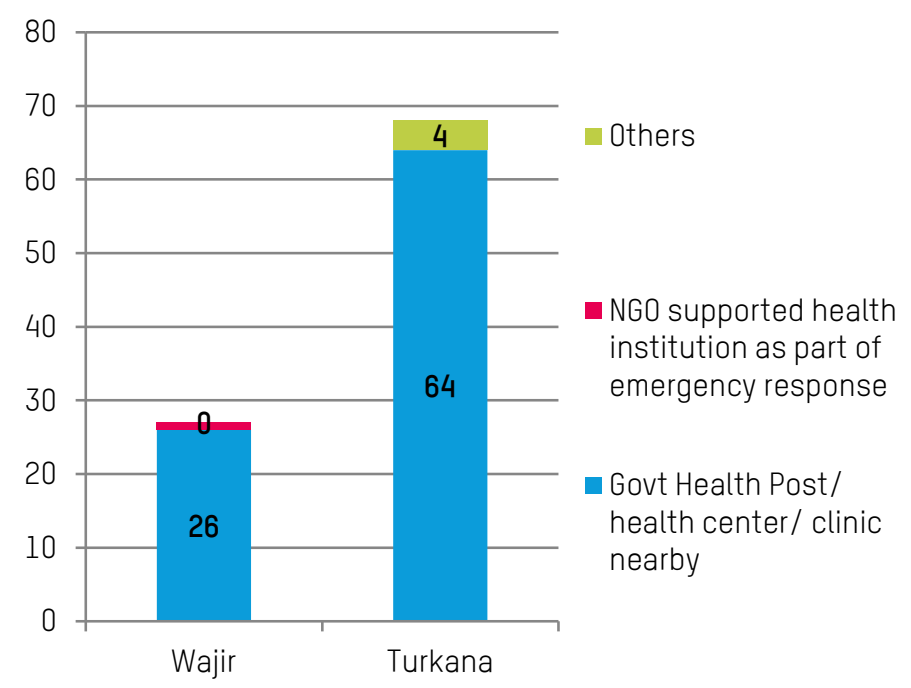

\section{Figure 11: Reason for lack of access to RH service}

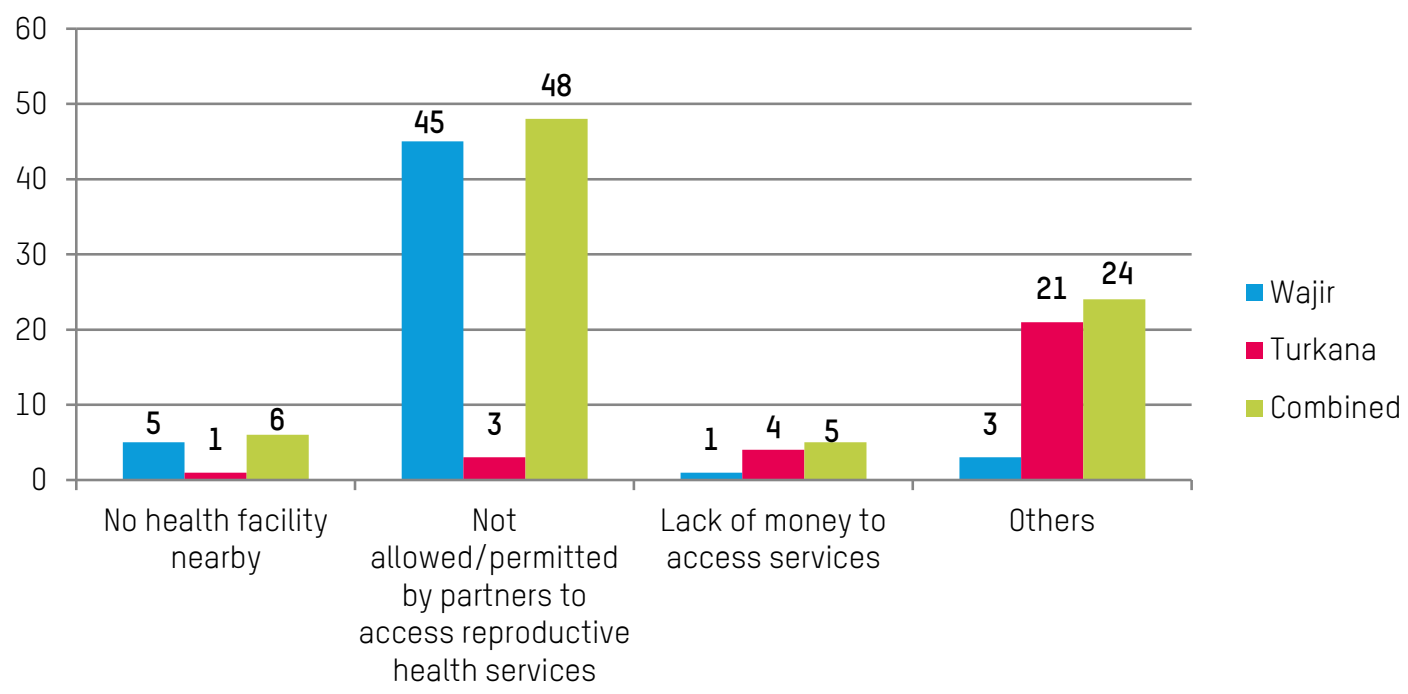

\subsubsection{Water, sanitation and hygiene, including menstrual hygiene}

\section{Water}

Borehole/water points are the main source of drinking water. Adult females (67 percent) and girls (12 percent) are the main water collectors (Figure 12), and fetch water twice in a day to meet daily needs. When asked how long a collector spends fetching water, 51 percent reported between 30 minutes and two hours. As reported by the respondents in Figures 13 and 14, water collection from one point to another is done by carrying the container on the back or head, mostly by women. Males in Turkana and Wajir use pull carts and animals to help them carry water, but the females do not. 
Figure 12: Collectors of water by sex

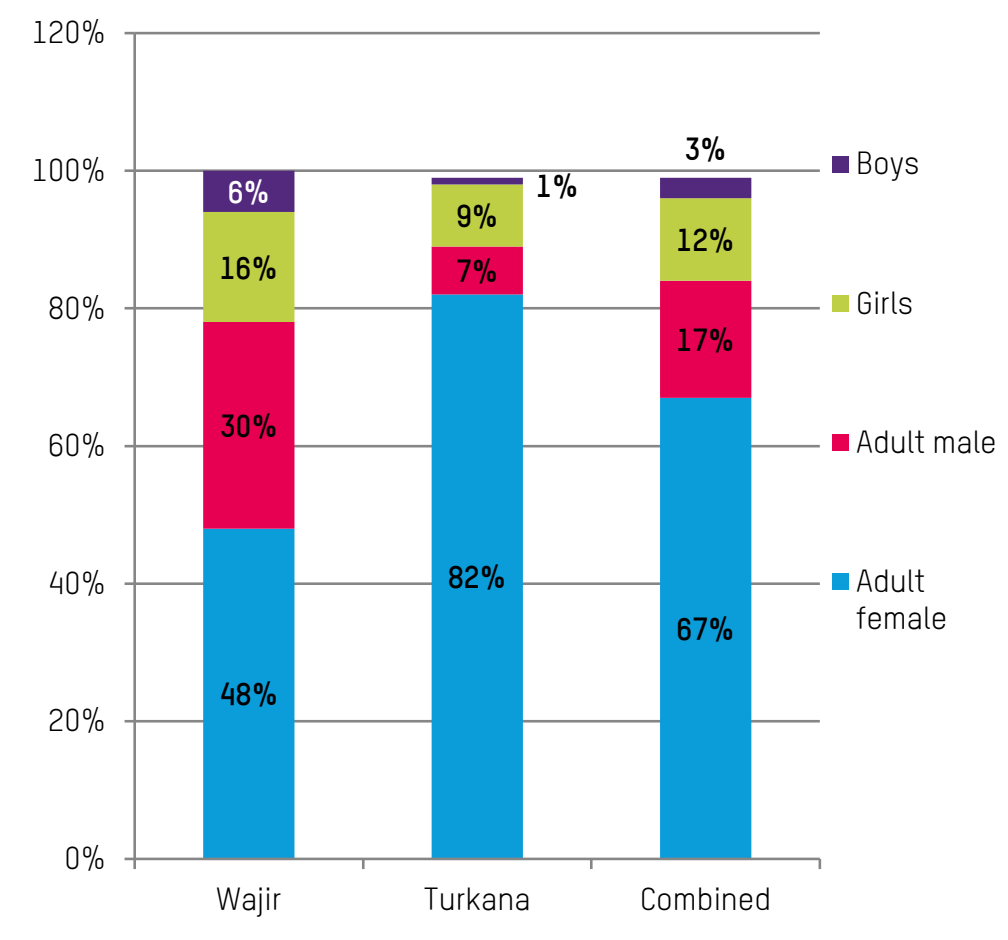

Figure 13: Water transportation by sex in Wajir

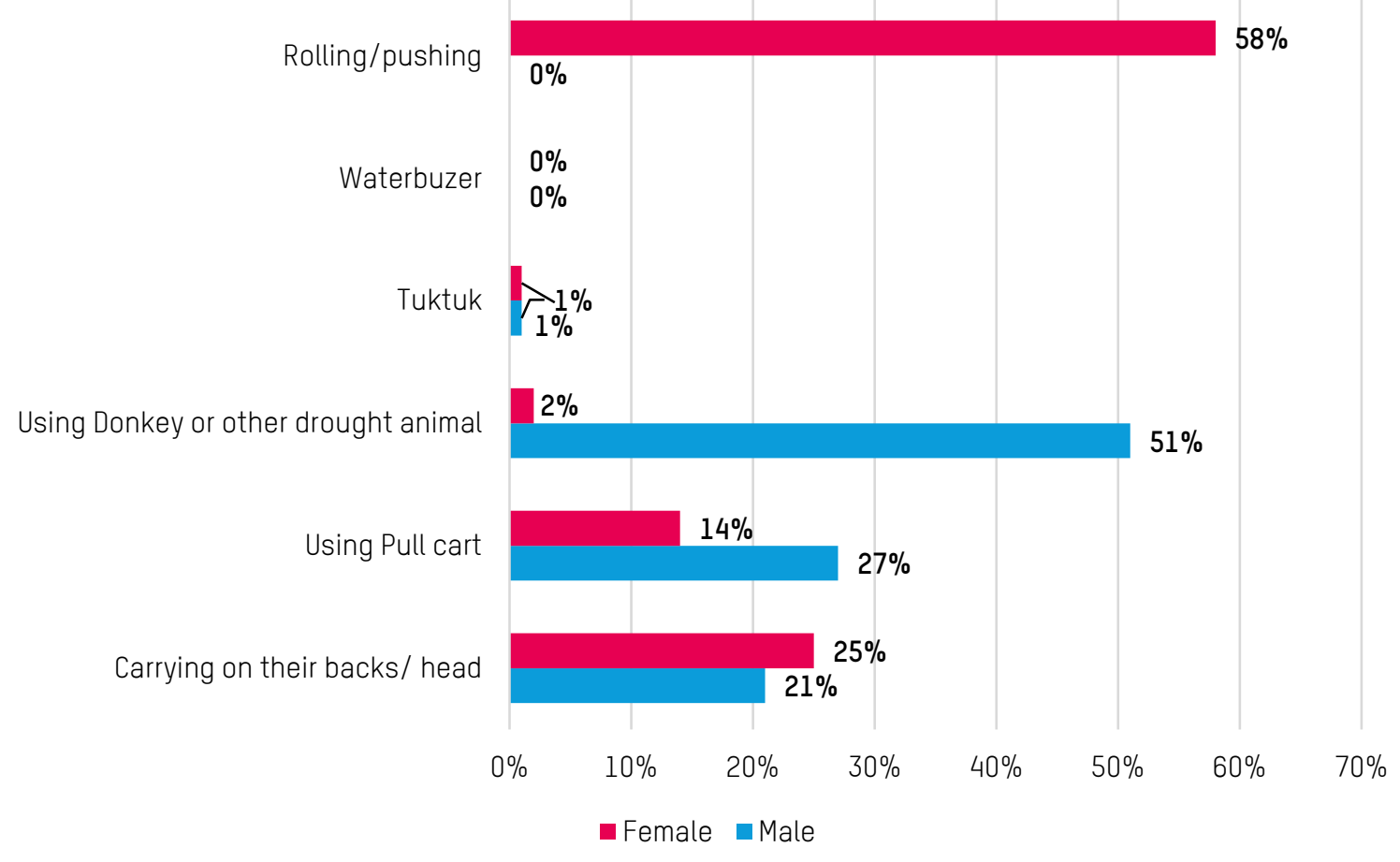


Figure 14: Water transportation by sex in Turkana

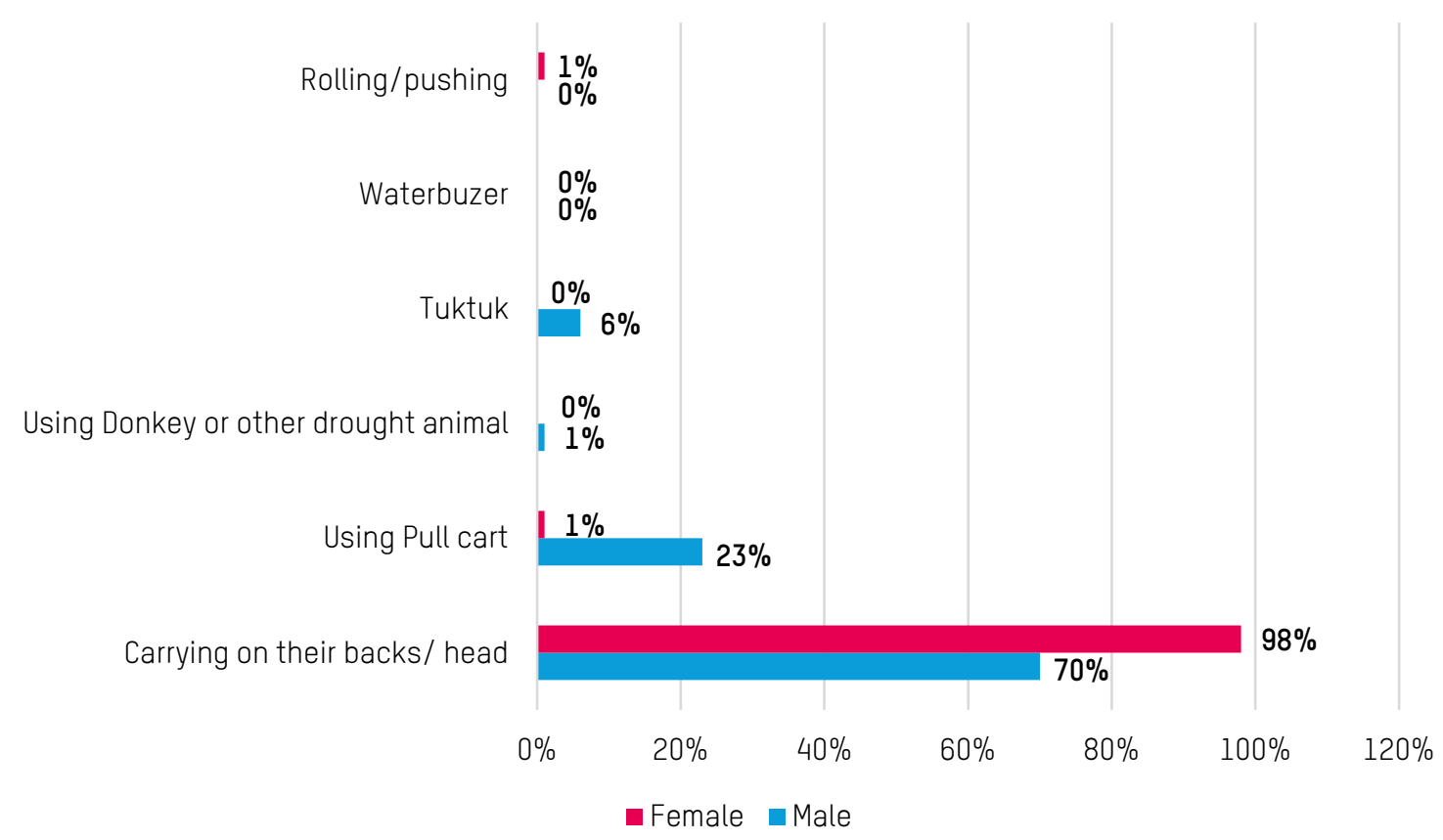

As shown in Figure 15 below, in terms of how safe water points were perceived to be, 22 percent of respondents believed the area was unsafe. Some women respondents (35 percent) said they addressed the situation by going to the water points in groups of women, and 33 percent said that they did nothing about it.

Figure 15: How poor perception of water point safety is addressed

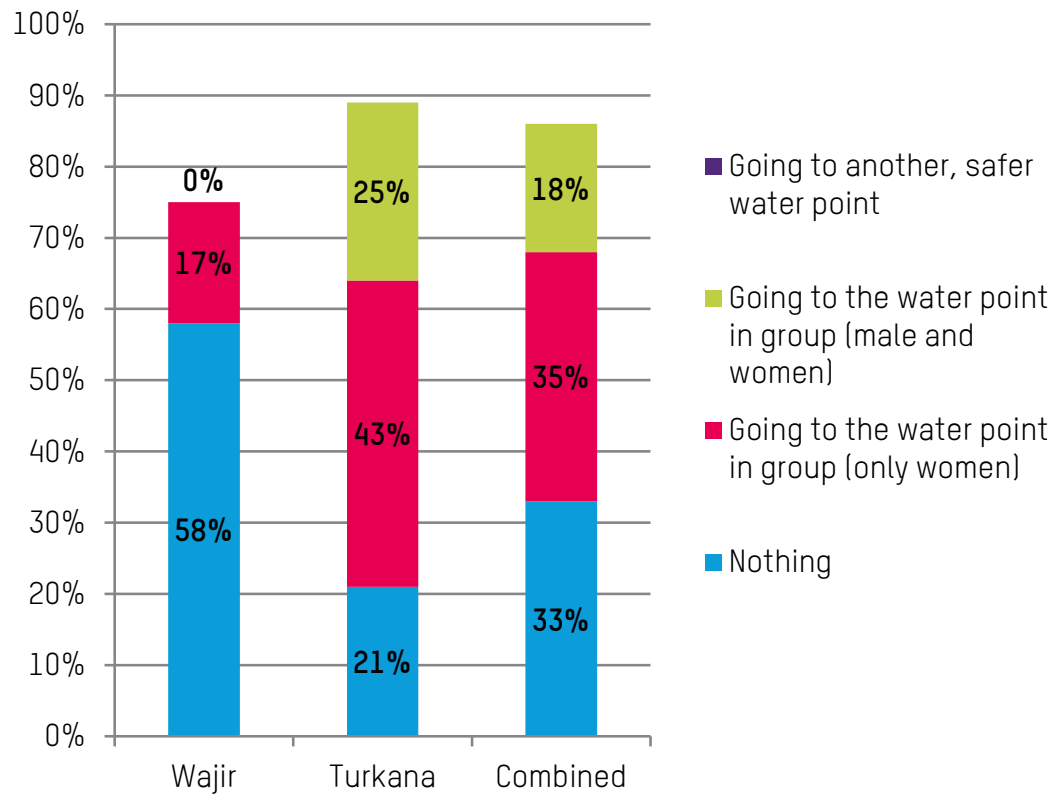

\section{Latrine and bathing facilities}

Sixty-three percent of respondents did not have access to latrines and 81 percent of them used open fields/bushes to relieve themselves. Fifty-three per cent of respondents did not have access to bathing facilities. 
When asked if they were using latrine facilities, 63 per cent of respondents said they were not, mainly because of insufficient lighting (53 per cent), lack of separate male/female toilets (52 per cent), and lack of lock/partition walls for privacy (52 per cent). (See Table 10.) In FGDs, women expressed experiencing fear and humiliation when men saw them defecating in bushes with no privacy at all. Some women feared losing self-respect, especially older women whose sons-in-law lived within the same community. It is unacceptable and undignified to be seen by sons-in-law and even for those with a toilet, the mother-in-law cannot use the same toilet as her son-in-law. So the mother-in-law ends up defecating in the bushes.

Community-led total sanitation (CLTS) is being implemented in some areas in Turkana that are also affected by the drought. There has been no discussion on how to balance the long-term objectives of this project against the short-term humanitarian needs.

\section{Table 10: Reasons why respondents don't use latrines}

\begin{tabular}{|l|l|l|l|}
\hline & & & \\
\hline Not secure at night & Wajir & Turkana & Combined \\
\hline Long distance from household & $64 \%$ & $13 \%$ & $37 \%$ \\
\hline Latrine is in an unsafe place & $66 \%$ & $5 \%$ & $34 \%$ \\
\hline No locks on the door or no doors/walls to provide privacy & $57 \%$ & $8 \%$ & $31 \%$ \\
\hline There is no water and it is dirty & $74 \%$ & $33 \%$ & $52 \%$ \\
\hline Insufficient lighting & $72 \%$ & $23 \%$ & $46 \%$ \\
\hline No separate toilets for males and females & $77 \%$ & $32 \%$ & $53 \%$ \\
\hline Others & $75 \%$ & $32 \%$ & $52 \%$ \\
\hline
\end{tabular}

Table 11 shows why respondents were not using bathing facilities. These included: lack of bathing facility (69 per cent), lack of privacy (60 per cent), lack of water ( 46 per cent), absence of separate facilities for males and females ( 45 per cent), and insufficient lighting ( 44 per cent).

\section{Table 11: Reasons why respondents don't use bathing facilities}

\begin{tabular}{|l|l|l|l|}
\hline \multirow{2}{*}{ No bathing place } & Wajir & Turkana & Combined \\
\cline { 2 - 4 } & $75 \%$ & $64 \%$ & $69 \%$ \\
\hline No water & $63 \%$ & $27 \%$ & $46 \%$ \\
\hline Not secure at night & $39 \%$ & $20 \%$ & $31 \%$ \\
\hline Lack of privacy (translucent tarpaulin sheet) & $55 \%$ & $66 \%$ & $60 \%$ \\
\hline Insufficient lighting & $53 \%$ & $34 \%$ & $44 \%$ \\
\hline No locks on the door & $47 \%$ & $18 \%$ & $34 \%$ \\
\hline No separate bathing facility for males and females & $51 \%$ & $39 \%$ & $45 \%$ \\
\hline
\end{tabular}

In FGDs, women and girls shared that they had to wait until night to shower in the dark, or use their own huts as bathing shelters, to ensure privacy. Teenage girls were fearful and preferred not to bathe in the open. But they also didn't feel safe bathing in the dark because of dangerous animals. Muslim women are not allowed to take a bath where they can be seen with no or lesser clothes. ${ }^{28}$ Women and girls said they were most affected during their menstrual periods, as men could go for more days without taking a bath. Women and girls in Turkana expressed that it was convenient to bathe at the water source, but they didn't feel safe doing that as they could be exposed to drunken men hovering around. They felt they were vulnerable of being raped.

\section{Menstrual hygiene}

Of Turkana's 64 female respondents, 63 reported using menstrual hygiene products before and during the drought. Increases were reported in the use of disposable sanitary pads (from 57 per cent to 62 per cent), the use of reusable cloths (from 21 per cent to 29 per cent) and the use of washing facilities (from 41 per cent to 48 per cent). Most respondents (40 per cent) purchased menstrual hygiene products from shops, 
while others (23 per cent) received them from humanitarian agencies. Table 12 presents how these products were mainly disposed of: by burying ( 41 per cent), throwing into latrines ( 27 per cent), and burning (23 per cent).

\section{Table 12: Disposal of menstrual hygiene materials}

\begin{tabular}{|l|l|l|l|l|l|l|}
\hline \multirow{2}{*}{$\begin{array}{l}\text { Disposal of menstrual hygiene } \\
\text { materials }\end{array}$} & \multicolumn{2}{|l|}{ Wajir } & Turkana & \multicolumn{2}{l|}{ Combined } \\
\cline { 2 - 7 } & No. & $\%$ & No. & $\%$ & No. & $\%$ \\
\hline Throw into latrines & 15 & $19 \%$ & 24 & $38 \%$ & 39 & $27 \%$ \\
\hline Burning & 22 & $27 \%$ & 12 & $19 \%$ & 34 & $23 \%$ \\
\hline Burying & 35 & $43 \%$ & 24 & $38 \%$ & 59 & $41 \%$ \\
\hline Using bins & 0 & $0 \%$ & 0 & $0 \%$ & 0 & $0 \%$ \\
\hline washing & 9 & $11 \%$ & 4 & $6 \%$ & 13 & $9 \%$ \\
\hline Total & 81 & $100 \%$ & 64 & $100 \%$ & 145 & $100 \%$ \\
\hline
\end{tabular}

Women expressed that women and girls had a good understanding of menstruation and that it was important to maintain hygiene. Elderly women usually educated young girls about it. This topic is not discussed in the presence of men and generally not in any public space. There are few cultural practices that are dominantly observed when women or girls have their period. They mentioned some clan-based beliefs which dictate what a woman should do or not do during her period. For example, some are not allowed to tend to their animals or sleep with their husbands. It is also shameful to be seen with soiled (bloodstained) clothing. In Wajir, where the majority are Muslims, they adhere to religious teachings around menstruation (for example, exempting menstruating women from fasting). ${ }^{29}$

During the drought, regardless of location or religion, women and girls faced challenges in terms of buying sanitary towels, as they mostly could not afford them. ISchools hand out sanitary towel to girls, but many girls have now dropped out of school. There is no institution that consistently hands out sanitary towels, especially to adult women.) They also faced challenges because water is scarce, making it more difficult to bathe and clean.

\subsubsection{Protection}

There is conflicting information on protection issues. Some respondents, especially in Wajir, said that there were no reasons to believe that people were at risk because of the drought. They expressed that women and girls were safe and that no unusual incidents were happening. However, based on their monitoring, the Ministry of Gender and Mercy Corps in Wajir, the International Rescue Committee (IRC) and the Diocese of Lodwar in Turkana have shared that GBV cases have been steadily increasing, especially during the drought. 'From January to June, the IRC received reports of 67 cases of rape of children aged nine to 16, an average of 11 per month. Before the drought, they saw one or two cases a month.' ${ }^{30}$ As shown in Table 13 , different risks were identified by women, men, girls and boys in the two counties. 


\begin{tabular}{|c|c|c|c|c|}
\hline Risks & Women & Girls & Men & Boys \\
\hline $\begin{array}{l}\text { Physical violence, even killings, occur between rival groups (probably inter- } \\
\text { clan in Wajir, and inter-tribe in Turkana). This happens during cattle rustling } \\
\text { or conflicts due to competing access and control over pastures and water } \\
\text { sources. There is a changing pattern of nomadism among pastoral } \\
\text { communities in past years. } 31 \text { Before, pastoral communities moved together } \\
\text { as entire households when they needed to look for new pastures for their } \\
\text { livestock. With the frequency of drought, many households segregated their } \\
\text { families with the strong (physically fit) ones (men and older boys) moving, } \\
\text { while the weaker ones were left in a more or less sedentary settlement. This } \\
\text { implies that once enemies come, they will go after the 'weaker' ones. }\end{array}$ & $x$ & $x$ & $x$ & $x$ \\
\hline $\begin{array}{l}\text { Gun violence has been increasing in Kenya due to the proliferation of illegal } \\
\text { firearms. Cattle rustling, which is traditionally associated with dowry, has } \\
\text { become commercialized. Pastoralists possess guns to rustle or to protect } \\
\text { themselves from rustlers. It is common to see pastoralist men especially } \\
\text { near the borders (both in Wajir and Turkanal carrying arms while herding. }{ }^{32}\end{array}$ & & & $x$ & $x$ \\
\hline $\begin{array}{l}\text { Domestic violence (wife beating) is socially acceptable. FGD groups narrate } \\
\text { that this drought is causing high stress which leads to increased conflict } \\
\text { between husbands and wives and ends up with wife beating. This is often } \\
\text { managed as a private affair. Only when a formal complaint is lodged with the } \\
\text { chief does it become an official concern. However, given the status of } \\
\text { women, women are unlikely to get favourable support. }\end{array}$ & $x$ & & & \\
\hline $\begin{array}{l}\text { Sexual violence such as harassment and rape are likely to happen to women } \\
\text { and girls as they walk further to collect water or firewood. Women and girls } \\
\text { have increased their exposure as they need to get and process raw materials } \\
\text { to produce charcoal. Historical accounts mention abduction of women } \\
\text { during cattle rustling. }\end{array}$ & $x$ & $x$ & & \\
\hline $\begin{array}{l}\text { Stealing, robbery and even mugging are increasing. These are particularly } \\
\text { attributed to drought. Older boys are identified as perpetrators. In urban } \\
\text { areas, they are probably stealing in the streets. Many are also under the } \\
\text { influence of alcohol and bhang (cannabis sativa). }{ }^{33}\end{array}$ & $x$ & $x$ & $x$ & $x$ \\
\hline $\begin{array}{l}\text { Political or election-related violence is also mentioned. Kenya had its } \\
\text { elections in August } 2017 . \text { In Wajir, }{ }^{34} \text { it is alleged that inter-clan feuds are } \\
\text { fuelled as well as used by politicians to drive non-supporters away from } \\
\text { voting sites. Drought is also used as a justification for this movement. }\end{array}$ & $x$ & $x$ & $x$ & $x$ \\
\hline $\begin{array}{l}\text { Early or child marriages are also occurring. In Turkana, forcing girls to marry } \\
\text { boda-boda drivers is prevalent in Kakuma. There are also cases where girls } \\
\text { voluntarily marry as a coping strategy, as reported in Natiir. In Wajir, it was } \\
\text { mentioned that marriage in general has decreased because people could not } \\
\text { afford the dowry. }\end{array}$ & & $x$ & & \\
\hline $\begin{array}{l}\text { Street related violence - IRC has been monitoring the abnormal increase in } \\
\text { the number of street children, particularly in urban centres. IRC has } \\
\text { monitored alarmingly high numbers in Turkana. }\end{array}$ & & $x$ & & $x$ \\
\hline $\begin{array}{l}\text { Prostitution: In Kakuma as well as Lodwar in Turkana, there is an increased } \\
\text { number of drinking pubs. These are said to be places where women and girls } \\
\text { are lured into prostitution. Men in Kakuma also narrated that mothers were } \\
\text { forcing their teenage daughters to have sex with boda-boda drivers to earn } \\
\text { money. IRC also shared that they suspected high levels of prostitution due to } \\
\text { the rise in numbers of street girl-children. }\end{array}$ & $x$ & $x$ & & \\
\hline
\end{tabular}

Related to child protection, IRC has been monitoring issues in urban/peri-urban communities. They noted 111 SGBV cases in just one week of monitoring in their outreach sites: Lomopus, Kapua, Kapokor, Lokormoru, Kankumeri, Moruongor and Nasiger. During IRC's monitoring on 24-25 February 2017, they counted 470 children on the streets between $7 \mathrm{pm}$ and lam. There is an unusually higher number of girls.

Conflicts in households have also been observed. (See Table 14 below.) Forty-one percent of respondents in the household survey reported that domestic conflicts were usually related to polygamous marriages, followed by 17 per cent reporting that conflicts arose because women engaged in culturally inappropriate roles.

Table 14: Sources of domestic conflict in households 


\begin{tabular}{|c|c|c|c|c|c|c|}
\hline \multirow{2}{*}{$\begin{array}{l}\text { Domestic conflict among } \\
\text { married couples predominantly } \\
\text { relates to: }\end{array}$} & \multicolumn{2}{|c|}{ Wajir } & \multicolumn{2}{|c|}{ Turkana } & \multicolumn{2}{|c|}{ Combined } \\
\hline & No. & $\%$ & No. & $\%$ & No. & $\%$ \\
\hline Decisions about money & 18 & $22 \%$ & 13 & $13 \%$ & 31 & $17 \%$ \\
\hline $\begin{array}{l}\text { Women engaging in culturally } \\
\text { 'inappropriate' roles }\end{array}$ & 1 & $1 \%$ & 36 & $37 \%$ & 37 & $21 \%$ \\
\hline Movement restriction & 2 & $2 \%$ & 3 & $3 \%$ & 5 & $3 \%$ \\
\hline Decisions about sale of animals & 6 & $7 \%$ & 7 & $7 \%$ & 13 & $7 \%$ \\
\hline $\begin{array}{l}\text { Husband marrying a second (or } \\
\text { third, etc) wife }\end{array}$ & 41 & $51 \%$ & 32 & $33 \%$ & 73 & $41 \%$ \\
\hline $\begin{array}{l}\text { One wife being favoured over } \\
\text { another }\end{array}$ & 5 & $6 \%$ & 5 & $5 \%$ & 10 & $6 \%$ \\
\hline $\begin{array}{l}\text { Decisions about children, e.g. } \\
\text { marriage, education }\end{array}$ & 8 & $10 \%$ & 1 & $1 \%$ & 9 & $5 \%$ \\
\hline Total & 81 & $100 \%$ & 97 & $100 \%$ & 178 & $100 \%$ \\
\hline
\end{tabular}

\subsection{GENDERED-DIFFERENTIATED COPING CAPACITIES AND STRATEGIES}

According to one study, 'Turkana pastoralists, like other nomadic communities, have traditionally used risk-spreading strategies over the years that include moving livestock to access the best quality pasture and water available, keeping species-specific herds to take advantage of the heterogeneous nature of their dis-equilibrium environment, and diversifying economic strategies to include agriculture, wage labour, and beekeeping among others. ${ }^{35}$ Other strategies employed included keeping herds containing a mixture of different livestock species as insurance against total loss of livestock in case of drought. The livestock included camels, cattle, sheep, goats, and donkeys, all of which have different forage and water requirements and variable levels of resilience to drought. The camels, cattle, and goats provide milk, which is consumed by the households. The small stock is sold when cash is required to meet other domestic requirements such as purchasing food or paying school fees. For a long time, a majority of the Turkana community raised their livestock mainly to meet subsistence and socio-cultural obligations. However, this practice has been changing in response to ecological and socio-economic changes ${ }^{36}$ as households increasingly embrace the market economy and offer more animals for sale than before.' 37 The findings in this assessment confirm these points. However, most of the coping mechanisms described above may have been already exhausted in the early months of the drought. This assessment was done after almost a year of drought, which implies that those with livestock would have probably sold them or the animals would have already died. A number of the possible coping mechanisms are risky and harmful.

\subsubsection{Coping through time}

As reflected in Figures 16 and 17 below, respondents described the coping mechanisms they had employed in the past seven days before the survey. FGDs confirmed the same practices. The selling of livestock and assets were affirmed as coping mechanisms, especially by men in Wajir. 
Figure 16: Coping mechanisms over past seven days (Turkana)

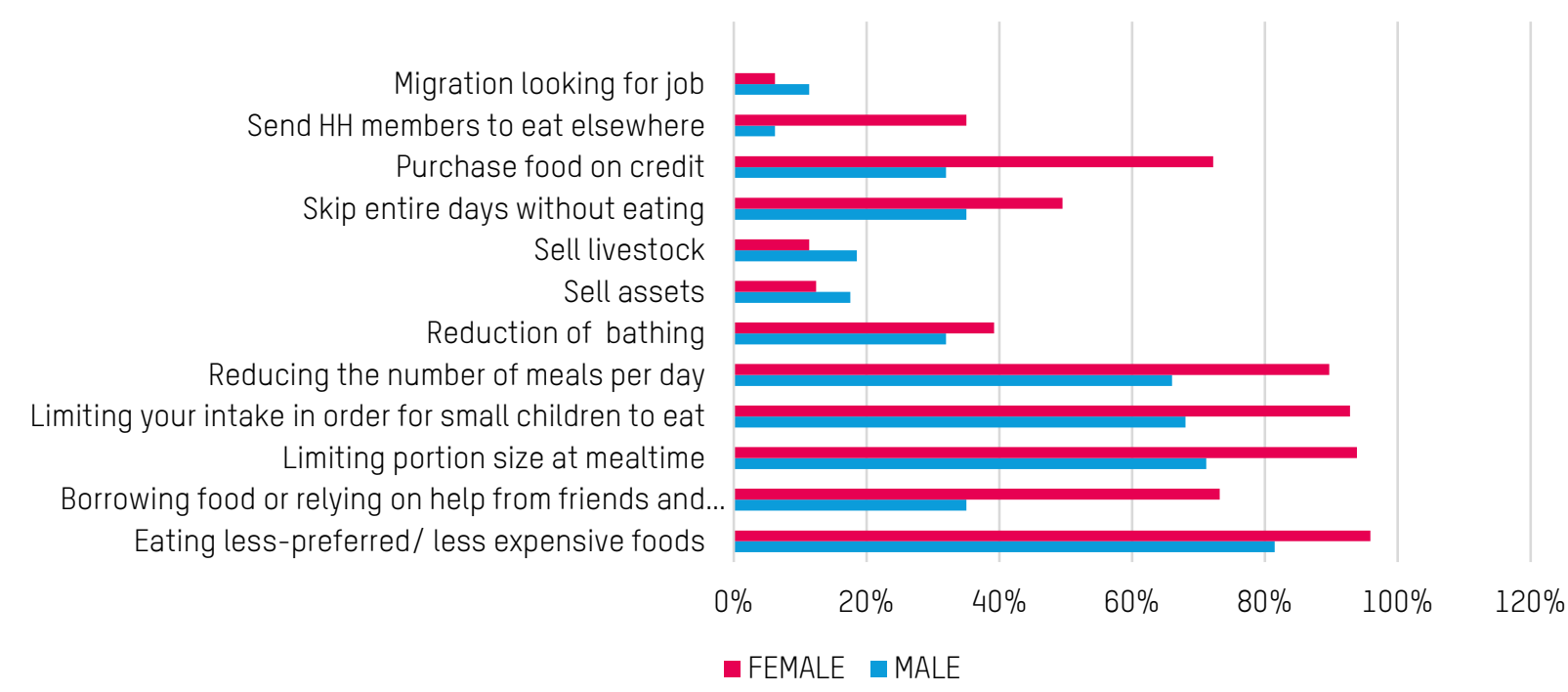

Figure 17: Coping mechanisms over past seven days (Wajir)

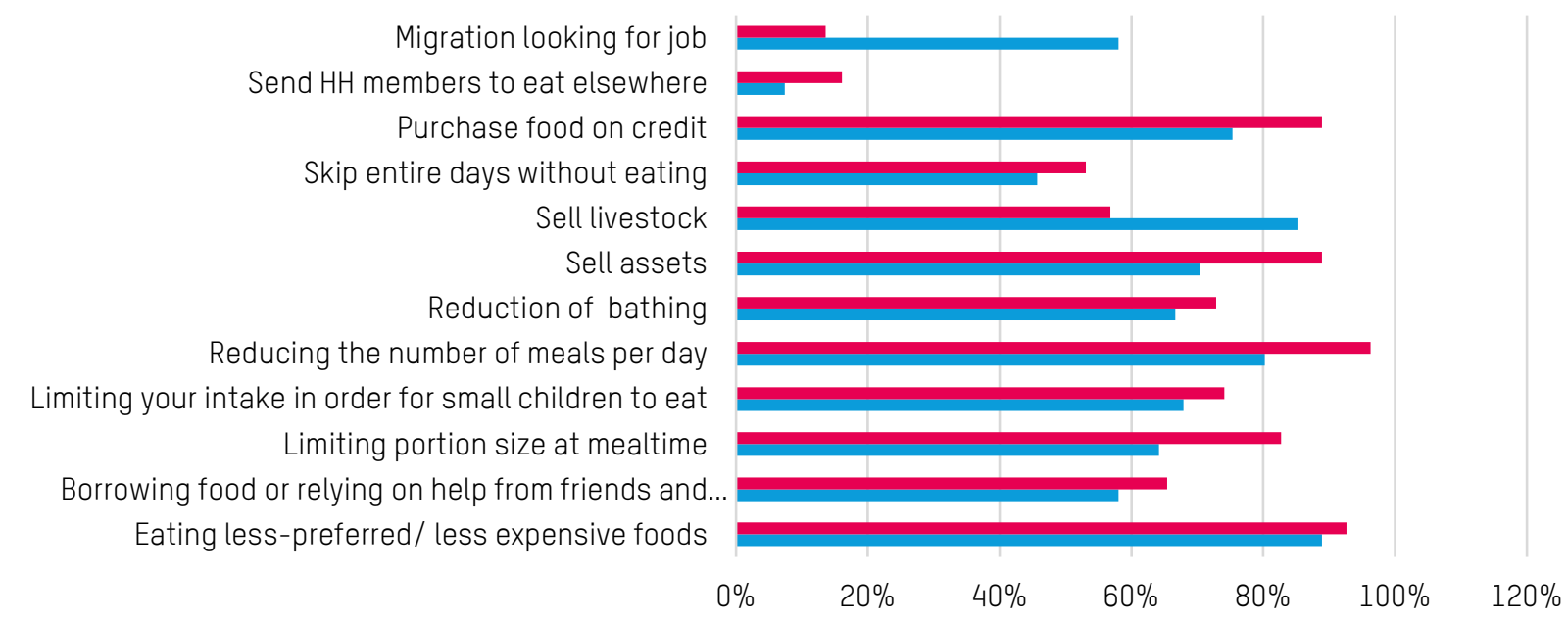

-FEMALE $\square$ MALE

\section{Food intake}

More women were sacrificing food intake than men in both areas through: eating less-preferred/less

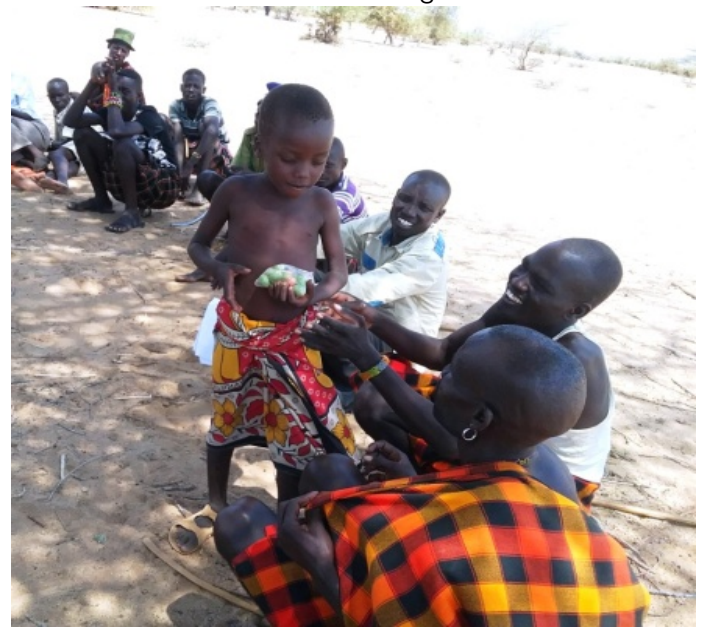
expensive foods; limiting portion sizes at mealtimes; limiting intake in order for small children to eat; reducing the number of meals per day; and skipping entire days without eating.

Ebei is a wild berry that children eat to sustain themselves throughout the day in Turkana. Photo: David Samal

\section{Moving to distant locations}

Pastoralists are nomadic and move from one place to another for pastures and water. 'Mobility is a well-known primary risk reduction strategy; particularly in times of drought [it is] employed by pastoralists exploiting rangelands [...] mobility is pursued primarily for livelihood purposes and is very strategic. ${ }^{38}$ Movement of livestock to 
areas with secure water and pasture resources is an effective strategy against droughts ${ }^{39}$ and has remained important for herders in north-western Turkana County of Kenya.' 40 This movement has been aggravated by the drought, which has exposed men and boys to insecure areas le.g. where there are existing conflicts) as they need to go further and even fight over resources. Furthermore, the uncertain conditions and prolonged separation from families cause a lot of mental stress among men. Partly, men are also stressed that they may no longer be able to provide for their families. Cases of suicide due to stress among men were mentioned in FGDs in Turkana. Respondents, especially in Wajir said that men more than women coped by migrating to look for work. Meanwhile, women and girls must travel far to fetch water or collect firewood, which exposes them to the risk of sexual assault. Both women and men are under great stress due to the various uncertainties, physical tiredness, mental stress and worries.

\section{Borrowing (loans and credit)}

In the survey, more women than men said they engaged in borrowing food or relying on help from friends and relatives, especially in Turkana. Similarly, more women than men said they purchased food on credit, especially in Wajir.

Figure 18 below shows that 136 respondents are currently in debt (in both counties). In Figure 19, 140 respondents (79 per cent) reported incurring more debt because of the drought. Traders are the main source of funds in Turkana, and lenders in Wajir (Figure 20). This is surprising because in Wajir borrowing with interest is considered haram (forbidden) for Muslims. The majority of these households reported using borrowed funds to purchase food, followed by payment of medical bills, settlement of debt and purchase of water.

Figure 18: Households with debts

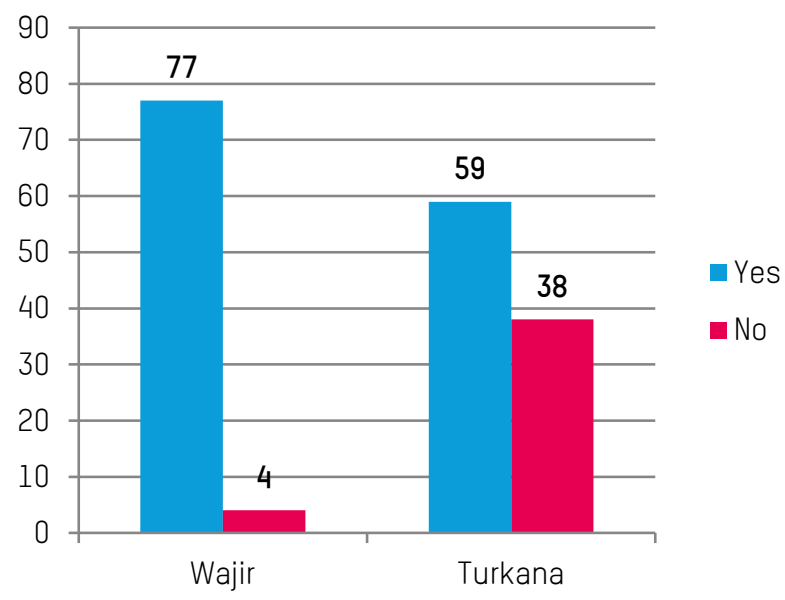

Figure 19: Households with increased debts during drought

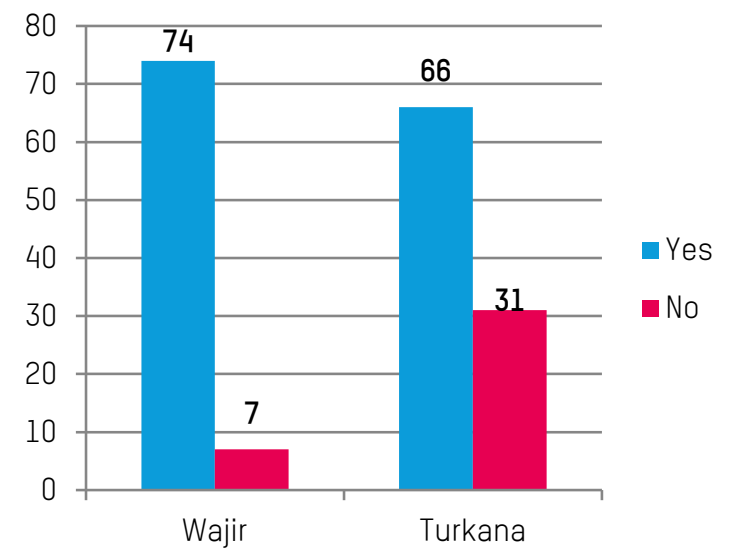


Figure 20: Source of debts

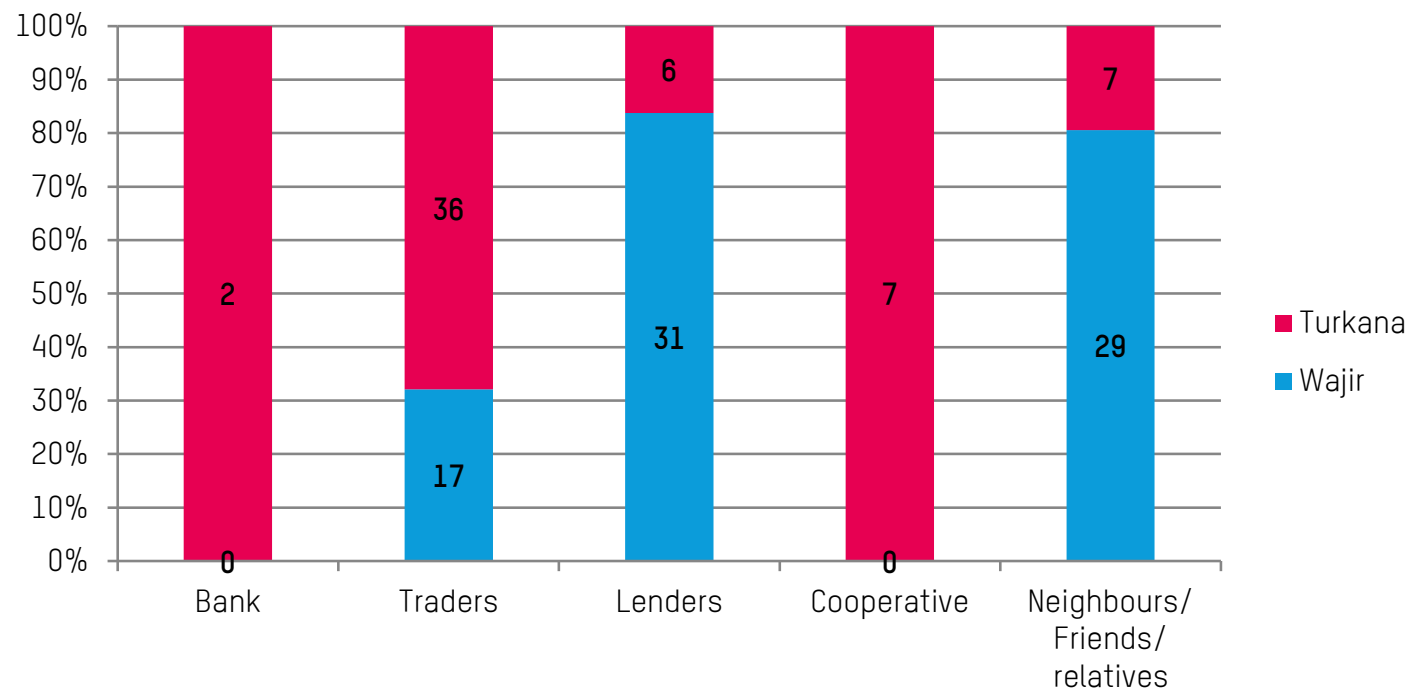

In one KII, a village chief expressed concern about the pressure of paying debts. He mentioned cases where beneficiaries received cash aid but the creditors were on standby and immediately took the money, resulting in a situation where families still could not buy food and meet other needs, even with cash assistance from government or NGOs.

\section{Support from relatives}

Some household members moved to stay with relatives (e.g. in towns) and depend on them for food. This was validated by KIIs in towns, where people are hosting many relatives and have increased their dependents by at least by 100 percent. One local NGO worker shared that she was feeding at least seven additional relatives. So she herself has skipped dinner for many months now. As they are often wage earners, hosts don't qualify for humanitarian aid. There is a very strong culture of sharing among pastoralists communities, especially among Somalis. This culture is threatened with the frequency of drought. Conflicts arise among families because of inadequate resources and competing needs.

\section{Early marriage}

The survey broadly expressed two views on early marriage: ${ }^{41} 1$ ) It has been going down through time. This is because more and more girls are going to school. Also, some respondents stated that early marriage during the drought was decreasing as there were no livestock to be used as dowry. 2) On the other hand, many said that the drought had further increased early marriage. Some said that because of hunger, teenage girls were given away to marriage to anyone who could pay. They particularly identified boda-boda drivers. It is not very clear if the girls are set to marry the drivers, or if the drivers are just serving as middlemen. Men respondents shared that in the past two months in Turkana Central there were four cases like this in Natiir, Eliye, and three in Maendeleo Kalokol.

\section{Harmful activities ${ }^{42}$}

Alcohol intake (of locally brewed alcoholic drink) has increased in Potokom, Nayanee, Napatet, Kaolokol and Locheregaal in Turkana for men, women and boys. Young boys are taking bhang, a dangerous and addictive substance, in Kalokol and Nayanae in Turkana. Meanwhile in Wajir, women are said to be selling miraa leaves, which are also dangerous and addictive, in Dasheg, Wajirbor, Dambas and Haragal. It is reported that even women leaders or women informal groups are selling miraa. Islam considers miraa as forbidden and women can be rejected by the whole community if they are known to be selling miraa. Engagement in criminal and violent activities were also mentioned in both male and female FGDs, including prostitution, stealing and cattle rustling. 


\subsubsection{Negative coping mechanisms}

Most of the respondents in both counties recognized that a number of their coping mechanisms had various detrimental effects on the individual and the whole community. In the FGDs, respondents identified which among the coping mechanism they wanted to immediately stop:

(a) Stealing, gambling, cattle rustling and other criminal activities. Young males are prone to committing them.

(b) Production, trading and use of dangerous and illegal or dangerous substance like local alcohol, miraa, bhang.

(c) Too much manual work, especially for women le.g. collecting and carrying gravel, burning charcoall as it makes them sick and can lead to miscarriage.

(d) Borrowing money - considered a demeaning practice.

(e) Charcoal production, as it depletes natural resources which livestock need, as well as destroying the environment.

(f) Activities that expose women and girls to sexual violence and prostitution le.g. walking long distances for firewood).

(g) Migrating long distances for pastures, exposing men to violence and physical harm as well as separating families.

\subsection{HUMANITARIAN ACTIONS AND GAPS}

\subsubsection{Humanitarian assistance}

Between May to June 2017, within a period of 30 days, a mere 19 per cent of the total 178 households of respondents from Wajir (14 per cent) and Turkana (23 per cent) received humanitarian assistance. Most of them heard about it from NGOs, church/mosque and neighbours. Major sources of assistance were NGOs (39 per cent) and the government (36 per cent) followed by UN agencies (12 per cent). Those who did not receive aid were asked why. Almost half ( 46 per cent) had no idea; others said there were no agencies that provided assistance, and the remaining 24 per cent mentioned various reasons.

Food, unconditional cash transfer, water, sanitary kits and livestock vaccination were the types of humanitarian assistance most received by respondents, as shown in Figure 21. Jerry cans, clothing and cooking utensils were the top three NFIs reported as most needed during these times. Given the context, it is a huge challenge for women to do domestic activities without these items. In terms of assistance for GBV, there was very minimal assistance in Wajir, and none in Turkana. 
Figure 21: Most pressing NFI items needed by households

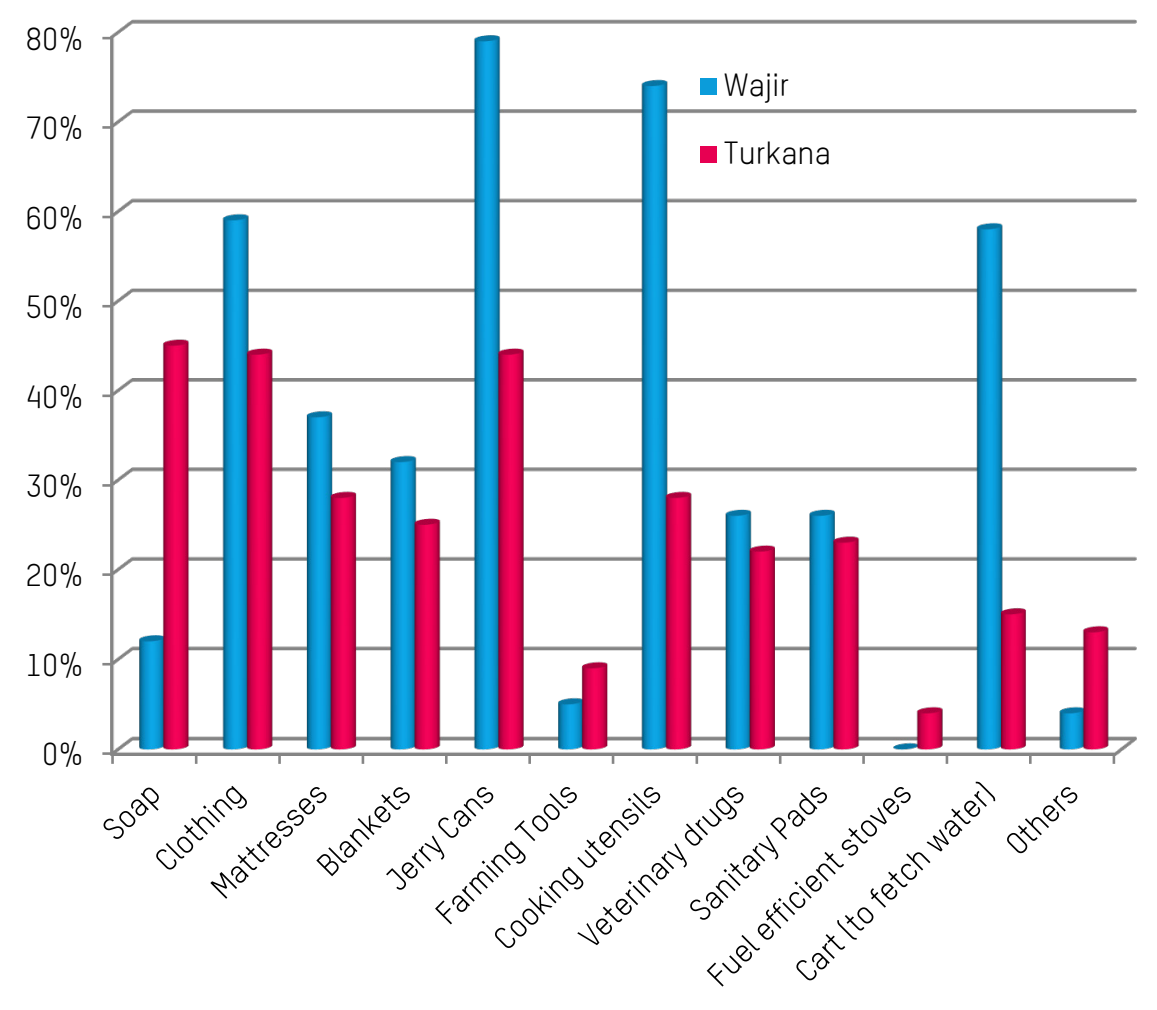

Seventy-five per cent of respondents reported not having access to food or CTPS. Cash for work activities, although happening in the counties, are mainly focused on carpentry/masonry (61 per cent), erosion control (59 per cent) and road maintenance (56 per cent).

As shown in Figures 22 and 23 below, men and women prefer to work on milk processing (89 per cent for men, 58 per cent for women), food preparation (71 per cent for men, 65 per cent for women) and smallholder vegetable production (56 per cent for men, 53 per cent for women). 
Figure 22: Activities preferred by men

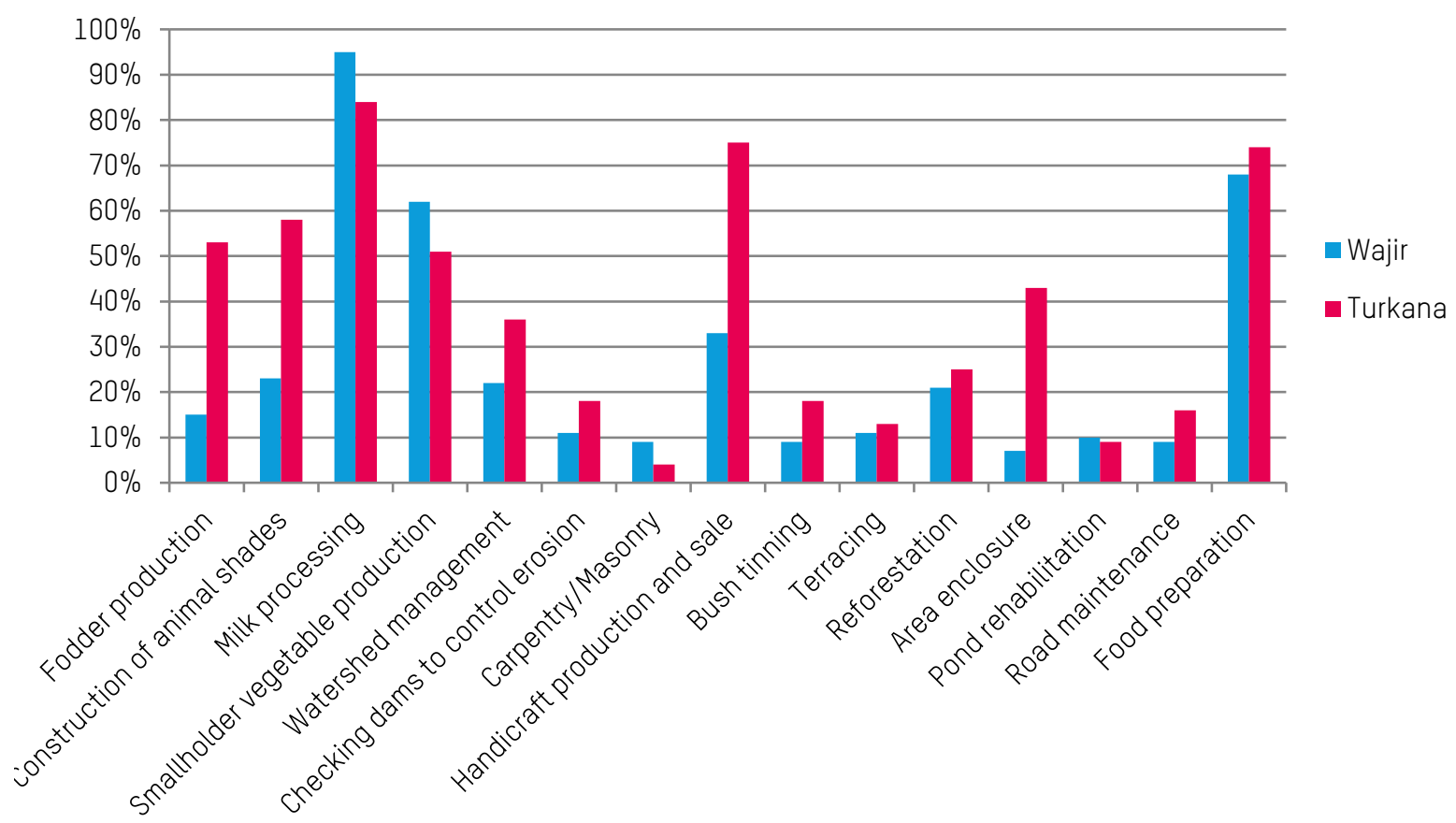

Figure 23: Activities preferred by women

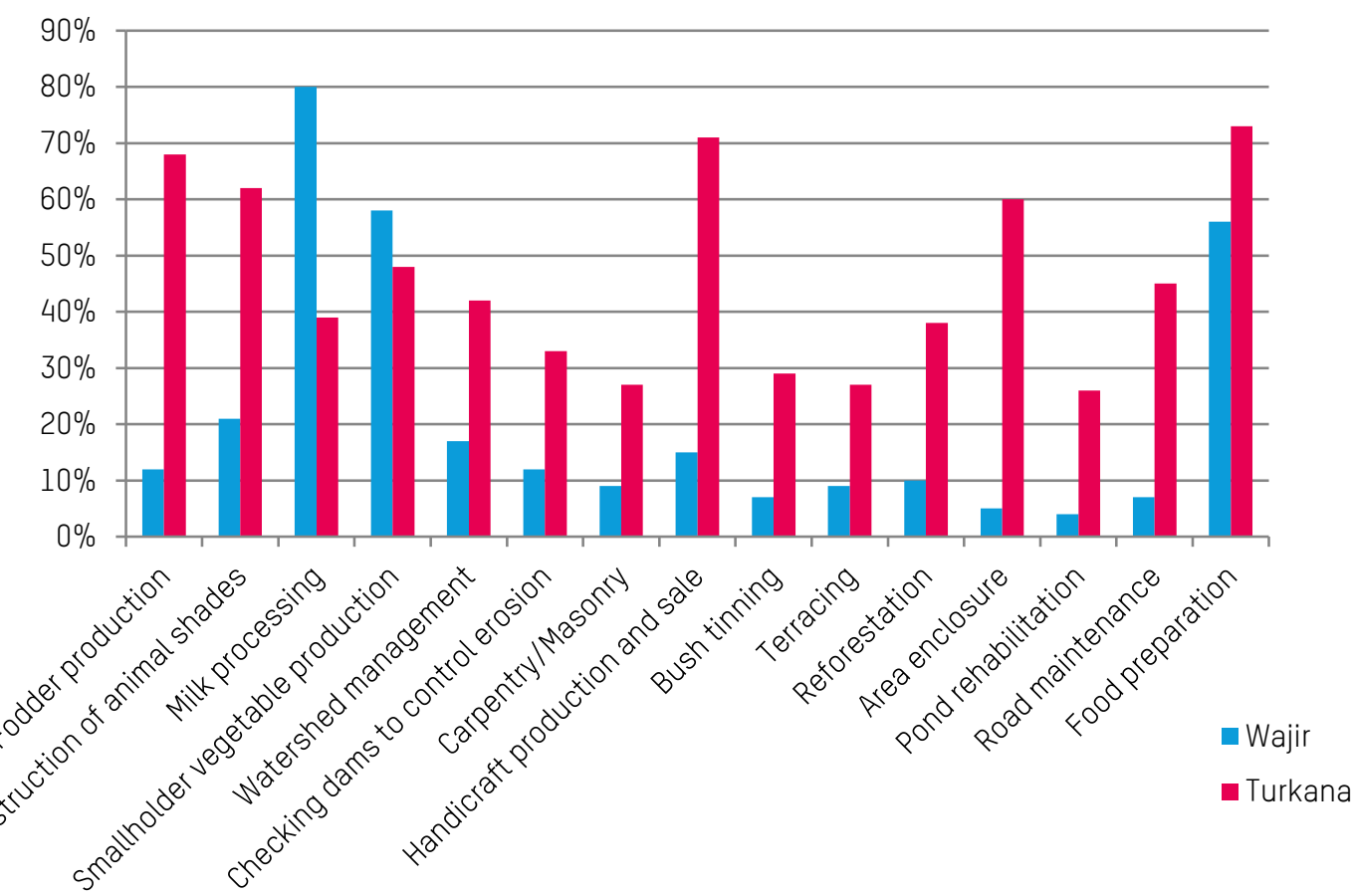

In terms of coordination, both counties have a County Steering Group (CSG) led by the county government and co-led by the NDMA. However, the CSGs are not meeting as frequently as needed given the intensity of the emergency. According to informants, the performance of county governments has improved greatly due to devolution. However, staff don't yet have enough capacity to implement or manage a drought response. NDMA has been transferring capacity to their county-level counterparts. Initial relief has been distributed quickly compared with the previous drought in 2010. However, resources are not adequate. Resources are allocated to all villages but the specific beneficiaries are not clear. Resources are usually given to whoever is available during distribution. Incidents have been reported where politicians are using the relief operation in election strategy. The NDMA has brought a lot of experience e from the 2010 drought. However, it has not 
yet adapted a strong gender and protection component. These aspects are not at all visible in the situation reports (SitReps), assessment tools, contingency and response plans, and other documents. Some community leaders have shared that the current responses lack feedback mechanisms. They said that in the previous response, where there were more INGOs, there was a clear feedback process. A local NGO also shared that as much as they want to install accountability mechanisms, they don't have the resources to do so. They don't have sufficient funds or qualified staff to manage the system. Donors and INGOs who are funding them exclude support on accountability activities.

\subsubsection{Protection mechanisms}

Many protection issues are handled primarily by the traditional leadership structures at community level. As mentioned, if they pertain to the violation of women's rights, there is either little chance of getting appropriate support through this structure, or the decisions are usually not favourable to the survivors.

GBV cases are left in the hands of community or customary mediation. In Wajir, the Ministry of Gender has a strong GBV programme and a functional referral pathway. In Turkana, this is usually provided by NGOs. However, because of inadequate budgets, most services are often accessible by those near the service providers. Remote villages are often excluded from support. Staff, including very concerned police officers, are sometimes forced to spend money from their own pockets to support survivors. In the different droughtrelated government documents, protection (especially GBV) is often not visible. It is not discussed in NDMA SitReps, or contingency and response plans, nor included on the agenda of the CSG.

Even among aid agencies, GBV is not well-resourced in drought emergency responses. IRC and Vétérinaires Sans Frontières Germany (VSF-G) both shared that they used to include women's protection funding but it was stopped in favour of 'life-saving' interventions.

In Kalokol, they acknowledged that a project called bargaining power had empowered women and girls and challenged men and traditional gender roles. Similarly, NGOs who are working on protection for women and children have been instrumental in changing norms that discriminate against women and girls.

The affected communities have shared some strategies they employ to protect themselves. Some are indigenous and practised over time. Protection is a major prescribed role for men. They protect their families, their livestock and other assets. Among pastoralist families, men design their settlement with protection in mind. They often surround their homestead with strong fences:

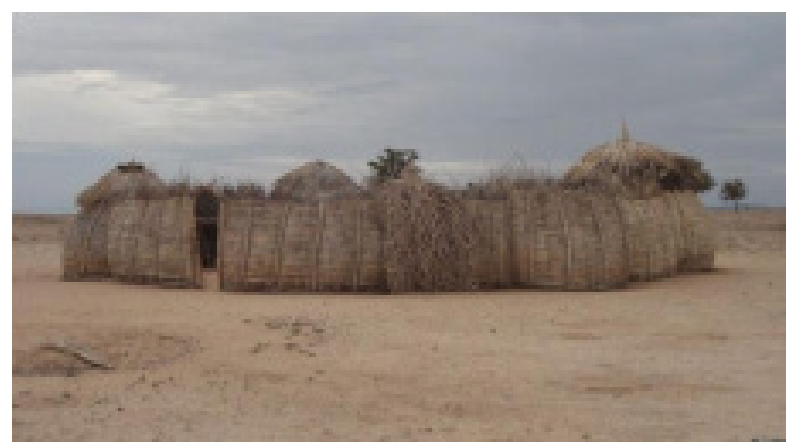

Household homestead with strong fence, Turkana.

Groups of related families, each with their own herd of cattle, may settle together and build around a central place. This system is preferred in settings where security of animals is paramount. (See the above photo showing a household. ${ }^{43}$

In segregated families (semi pastoralist), when the head of household has to leave with their livestock and move to distant places, they sometimes assign older boys as the protectors. As mentioned, more and more families are illegally acquiring guns for fighting or protection. In 2016, there were more than 600,000 illicit arms circulating in Kenya - particularly among the pastoralist communities in North Rift, North Eastern and Upper Eastern. ${ }^{44}$ There is no evidence to indicate that women are also using guns. 


\section{RECOMMENDATIONS}

\subsection{HUMANITARIAN DIRECT ASSISTANCE}

\begin{tabular}{|c|c|c|}
\hline Needs & Interventions & $\begin{array}{l}\text { Contribution to gender equality and } \\
\text { promotion of women's leadership }\end{array}$ \\
\hline $\begin{array}{l}\text { Food security } \\
\text { It has been } \\
\text { identified in this } \\
\text { report that } \\
\text { pregnant/breast- } \\
\text { feeding women and } \\
\text { those with } \\
\text { disabilities are not } \\
\text { given any priority for } \\
\text { food intake. Specific } \\
\text { targeting must be } \\
\text { done to reach these } \\
\text { groups. }\end{array}$ & $\begin{array}{l}\text { Food aid is within the control of women } \\
\text { while cash is controlled by men. A } \\
\text { combination of food, non-food and cash } \\
\text { interventions should be provided. They } \\
\text { can be conditional or unconditional cash } \\
\text { transfers. } \\
\text { Cash Transfer Programme } \\
\text { - Cash transfer should support more } \\
\text { pastoral-related activities and } \\
\text { should include gender-specific } \\
\text { work like cash for lincluding carel } \\
\text { work that targets women } \\
\text { Explore cash for support of } \\
\text { women's leadership; or cash for } \\
\text { supporting women to be gender } \\
\text { advocates } \\
\text { Explore cash support to youth: } \\
\text { male/female gender community } \\
\text { mobilizers } \\
\text { Food vouchers are good } \\
\text { alternatives if suppliers are } \\
\text { accessible and transactions costs } \\
\text { are not carried by beneficiaries }\end{array}$ & $\begin{array}{l}\text { In the case of heavy debts, cash is } \\
\text { received and automatically paid to } \\
\text { creditors. Beneficiaries may then still } \\
\text { not be able to buy food and meet } \\
\text { other basic needs. Giving different aid } \\
\text { packages facilitates opportunities for } \\
\text { women to access and control these } \\
\text { resources. } \\
\text { Conditional cash transfer can be a } \\
\text { powerful tool to increase women's } \\
\text { participation and leadership. }\end{array}$ \\
\hline $\begin{array}{l}\text { Livelihoods } \\
\text { Girls and boys } \\
\text { (youth) are } \\
\text { engaging in harmful } \\
\text { activities that } \\
\text { expose them to } \\
\text { many protection } \\
\text { risks. This group } \\
\text { should also be } \\
\text { targeted for } \\
\text { alternative } \\
\text { livelihoods work. }\end{array}$ & $\begin{array}{l}\text { Support what is still left of pastoral- } \\
\text { based livelihood assets and activities. } \\
\text { Remaining livelihood assets of women } \\
\text { should also be supported, not just men's } \\
\text { le.g. livestock re-stocking for both } \\
\text { women and men, plus supporting } \\
\text { women-specific individual or collective } \\
\text { activities like milk processing and } \\
\text { trading.) A gendered value chain analysis } \\
\text { should be done to understand what } \\
\text { gender-specific livelihoods are possible. } \\
\text { Markets can be supported with lesser } \\
\text { barriers to entry to women and other } \\
\text { vulnerable groups. } \\
\text { Support is needed for non-pastoral/new } \\
\text { livelihood activities that were identified } \\
\text { to diversify income. } \\
\text { Promote household livelihood } \\
\text { diversification that engages both women } \\
\text { and men, to strengthen economic } \\
\text { resilience. } \\
\text { Interventions should support } \\
\text { reproductive activities (care work) if and } \\
\text { when women are spending many hours } \\
\text { on productive activities. }\end{array}$ & $\begin{array}{l}\text { There is a continuous shift from } \\
\text { exclusively pastoral-based } \\
\text { livelihoods to other livelihood options. } \\
\text { More women are engaging in paid } \\
\text { labour as well as petty trading. This } \\
\text { will continue to re-define traditional } \\
\text { gender roles. This gives opportunities } \\
\text { for both women and men, as well as } \\
\text { girls and boys, to shift between } \\
\text { productive and reproductive roles. }\end{array}$ \\
\hline
\end{tabular}




\begin{tabular}{|c|c|c|}
\hline & $\begin{array}{l}\text { Promote women's leadership in } \\
\text { livelihoods committees. }\end{array}$ & \\
\hline $\begin{array}{l}\text { WASH } \\
\text { Cultural practices } \\
\text { exist that are } \\
\text { discriminatory } \\
\text { against mothers-in- } \\
\text { law. For example, } \\
\text { they are not allowed } \\
\text { to use the same } \\
\text { toilets as their } \\
\text { sons-in-law. This is } \\
\text { a small but also } \\
\text { highly vulnerable } \\
\text { group. }\end{array}$ & $\begin{array}{l}\text { Market-based approaches are positive, } \\
\text { but they should support all the relevant } \\
\text { actors in the supply chain as well as the } \\
\text { demand chain. } \\
\text { Conditional cash for water gives } \\
\text { beneficiaries purchasing power, but } \\
\text { does not resolve market access issues. } \\
\text { Market barriers such as transaction and } \\
\text { transportation costs should be included } \\
\text { in the formula. If bringing goods from } \\
\text { suppliers to beneficiaries is a better } \\
\text { solution, the costs of bringing the goods } \\
\text { should be covered. Otherwise, women } \\
\text { who are responsible for collecting water } \\
\text { will continue to have water access } \\
\text { challenges, and be exposed to more } \\
\text { harm. } \\
\text { Latrine and bathing facilities should } \\
\text { follow international standards to address } \\
\text { the practical, social and cultural issues } \\
\text { that were mentioned (e.g. locks, gender } \\
\text { separation). Ways must be considered to } \\
\text { redesign existing CLTS programmes so } \\
\text { that they fit the humanitarian context } \\
\text { better. } \\
\text { Explore culturally appropriate and locally } \\
\text { accessible menstrual hygiene } \\
\text { management related needs, e.g. } \\
\text { outsource AfricaPads (reusable } \\
\text { menstrual pads), which are produced } \\
\text { locally by women and serve as a source } \\
\text { of income. } \\
\text { Further support women's leadership in } \\
\text { water/ waste management committees. }\end{array}$ & $\begin{array}{l}\text { Strict traditions and norms govern } \\
\text { behaviour and decisions around water } \\
\text { collection, defecation and bathing. } \\
\text { These norms are linked to gender } \\
\text { roles. WASH interventions can } \\
\text { reinforce positive shifts in gender } \\
\text { roles, as well as stopping any harmful } \\
\text { practices. } \\
\text { Through committees that are formed } \\
\text { to engage beneficiaries in WASH } \\
\text { activities, women are given an } \\
\text { opportunity to participate. This can } \\
\text { also pave the way for greater } \\
\text { women's leadership. }\end{array}$ \\
\hline Non-food items & $\begin{array}{l}\text { NFI provision should cater to specific } \\
\text { gender groups, e.g. } \\
\text { - NFIs that target particular groups } \\
\text { such as pregnant and breast- } \\
\text { feeding women, infants and the } \\
\text { elderly. } \\
\text { NFIs should include kitchen } \\
\text { utensils las mentioned, the top } \\
\text { three most pressing NFI needs are } \\
\text { jerry cans, clothing and cooking } \\
\text { utensils). }\end{array}$ & $\begin{array}{l}\text { Women are dominantly responsible } \\
\text { for reproductive care work. They are } \\
\text { responsible for ensuring that } \\
\text { everyone under their care is fed. They } \\
\text { do everything to provide household } \\
\text { access to food, from sourcing to food } \\
\text { preparation and actual feeding. } \\
\text { Cooking is a central activity and can } \\
\text { be highly difficult under current } \\
\text { conditions. Kitchen and cooking NFIs } \\
\text { are essential to decrease the burden } \\
\text { on women and assist them in their } \\
\text { cooking role, as well as for securing } \\
\text { family food access and welfare. }\end{array}$ \\
\hline $\begin{array}{l}\text { Health/reproductive } \\
\text { health }\end{array}$ & $\begin{array}{l}\text { Health ranks first in the categorization of } \\
\text { needs. There are alarming indications of } \\
\text { mental stress, especially among men. }\end{array}$ & $\begin{array}{l}\text { Women and men suffer distinct health } \\
\text { disadvantages in different situations } \\
\text { and for different reasons, because of }\end{array}$ \\
\hline
\end{tabular}




\begin{tabular}{|c|c|c|}
\hline $\begin{array}{l}\text { Women and men } \\
\text { have distinct health } \\
\text { needs. }\end{array}$ & $\begin{array}{l}\text { The referral pathway for psycho-social } \\
\text { interventions should be supported. } \\
\text { Reproductive health issues are gender } \\
\text { specific, so these interventions should } \\
\text { cater to both women and men. }\end{array}$ & $\begin{array}{l}\text { differences in biology and gender } \\
\text { roles. } \\
\text { Women's health issues are getting a } \\
\text { slow but steady growth in attention in } \\
\text { humanitarian settings. Support for } \\
\text { women is relatively available, though } \\
\text { often inadequate. However, men's } \\
\text { health issues (especially reproductive } \\
\text { and mental health issues) are more } \\
\text { invisible. } \\
\text { For example, in this context, mental } \\
\text { stress is very much attributed to the } \\
\text { self-identity of male gender roles. The } \\
\text { inability to perform as provider or } \\
\text { protector causes anxiety, health } \\
\text { problems and even suicide. }\end{array}$ \\
\hline $\begin{array}{l}\text { Protection } \\
\text { Women and girls; } \\
\text { GBV issues are } \\
\text { glaring. }\end{array}$ & $\begin{array}{l}\text { The severity of protection issues in this } \\
\text { context is alarming. Conflict, crime, and } \\
\text { GBV are all increasing. Given these } \\
\text { trends, protection requires stand-alone } \\
\text { and long-term programmes that will } \\
\text { really support protection mechanisms, } \\
\text { as well as provide mitigation and } \\
\text { prevention interventions that target } \\
\text { specific groups. A protection } \\
\text { assessment is being separately } \\
\text { conducted, which will generate more } \\
\text { specific recommendations. }\end{array}$ & $\begin{array}{l}\text { Women and girls are largely affected } \\
\text { by sexual violence, and men and boys } \\
\text { by conflict and crime. } \\
\text { Referral pathway and services should } \\
\text { be made available/supported. } \\
\text { Invest in awareness building and } \\
\text { preventive activities. This should also } \\
\text { be integrated into long-term } \\
\text { programmes. } \\
\text { All Oxfam programmes and teams } \\
\text { should make a deliberate effort to } \\
\text { reduce protection risks, and should } \\
\text { ensure that their activities are safe } \\
\text { and do not cause harm. }\end{array}$ \\
\hline
\end{tabular}

\subsection{KEY ACTORS}

a. Government agencies. Gender is not visible in humanitarian coordination, as an agenda, plan or even as specific actions. There is a need to influence the CSG, NDMA and other legitimate agencies who are leading the drought response. There is a need to introduce/strengthen government competency on gender mainstreaming, especially among the leadership of the CSG, NDMA and county Disaster Management departments. There is also a need to strengthen the capacity of sector-specific agencies who are leading sector-specific responses le.g. Ministry of Health, Ministry of Water). The humanitarian coordination system should be strengthened to include the establishment of a Gender in Humanitarian Response working group lif already existing, this should be strengthened and given the mission to lead gender coordination in the response and recovery). Tools used by the CSG from assessment to planning should be reviewed, and advocacy for gender mainstreaming in all the tools should be undertaken.

b. United Nation agencies. The government is strongly leading the response but there are pockets of capacity gaps. Relevant UN agencies should support in strengthening capacity and coordination, as well as influencing their respective counterparts. For example, UN Women should work with the Ministry of Gender to support gender assessments and utilizing their recommendations throughout the response. 
C. INGOs. Most INGOs have limited funding to support gender mainstreaming in response and standalone programmes. There is a challenge but also an opportunity to come together to raise funds (e.g. through consortia).

d. Local NGOs. Capacity-building is needed on more specific gender mainstreaming or gendertargeted actions.

e. WROs. Given that there are few WROs involved in humanitarian action, special attention should be given to them through comprehensive and long-term support for funding, staffing and capacity building, so that they can lead on gender in emergencies. I/NGOs should engage with WROs in humanitarian action and support their competency.

f. Donors. Donors need to prioritize the funding of gender analysis in assessments, monitoring and review; as well as response actions that respond to different gender needs. Donors must ensure that funding support is sustained in gender mainstreaming and GBV prevention from response to recovery, to ensure shifts in attitudes and promote women's leadership.

\subsection{WOMEN'S ROLES AND LEADERSHIP}

- Reinforce more systematic awareness and capacity building on gender equality and women's rights. This should include targeting and engaging men and boys.

- Ensure women's voice are heard, and create spaces for women's leadership and representation at community level.

- Attention should be given to providing women a better fall-back position in both the reproductive and productive spheres. For example, cash for work should be able to mainstream cash for care work, as well as other types of work. This will enable women to participate, earn and at the same time perform their reproductive role.

- Enhance women's confidence and negotiation power through comprehensive capacity development support on their rights, including economic, legal and political rights.

\subsection{LONG-TERM VIEW}

- Gender inequality does not happen exclusively during a crisis. Crises often exacerbate existing gender inequalities. Therefore, there is a need for comprehensive and effective gender mainstreaming, as well as standalone women's rights programmes. The gains made on gender equality during a humanitarian response must be sustained by actors and institutions in the long term.

- It is imperative to adopt a one-programme approach that connects humanitarian and development programming. A strong campaign may focus on drought being the 'new normal', which will continue to differently affect women, men, girls and boys.

\subsection{RESEARCH}

- Changing economy. There is a trending shift or diversification from pastoral-based livelihoods to market-based livelihoods (trading and labour), including a growth in urbanization. Extraction industries are pushing out communal land use. There are also increasing labour demands on women and households. In-depth study is recommended to understand all these dynamics. This will provide better background on how to deal with drought, through both humanitarian and development lenses.

- Negative or harmful coping mechanisms. This assessment has found evidence of emerging or increasing negative coping mechanisms to deal with the effects of drought. In previous droughts, these behaviours were minimal. Examples include prostitution among girls in Turkana, increased debts in both counties, and young males engaging in criminal activities. More study is recommended to understand these behaviours and find ways to mitigate them. 


\section{CONCLUSION}

In the 2009 census, the population of the country stood at 38,610,097, comprising 19,417,639 females and $19,192,458$ males. The male-female ratio varies from region to region. 'The Government's commitment and efforts to promote gender equality and women's empowerment are reflected in the ratification of numerous international conventions and instruments such as Convention on Elimination of all forms of Discrimination Against Women (CEDAW), Beijing Declaration and Platform for Action, and the United Nations Universal Declaration of Human Rights, among others. The Government has instituted various laws and policy frameworks, set up several bodies at national as well as decentralized levels to advance, coordinate and monitor gender issues with more emphasis on production of gender disaggregated data at all levels for planning purposes. ${ }^{4} 5$ Despite the spirit of these gender frameworks, they do not necessarily translate to the transforming of patriarchal culture among pastoral communities such as those in Wajir and Turkana. This report has explained the power relations between women and men, which basically place women in a more disadvantaged position. The findings highlight the differential impact of drought on women and men, and to some extent girls and boys. There is no doubt that women and girls bear the greatest burden of drought. The more frequent and intense droughts are in these two areas land most likely, drought will be the 'new normal'), the greater the burden women must carry in terms of performing reproductive and productive roles, as well as additional community roles.

Despite the seemingly worse situation for women, opportunities are also emerging where gender roles are shifting. As life becomes tougher le.g. livelihoods disappear, food becomes scarce, health deteriorates, resources shrink), the space is growing for women to make decisions on access to (and to some extent control of) resources, and even to engage in non-traditional activities. Men may not thoroughly approve it, but for survival reasons, they allow it. This unlikely consent may not have happened without the drought. As drought is expected to continue or occur more frequently in the future, changes in gender roles may potentially be sustained. These small changes are akin to drops of water sinking into the ground. As time goes by, water accumulates beneath the dry lands, shifting attitudes and dynamics for women and men in Turkana and Wajir. 


\section{REFERENCES}

Abdirahman, Fat-Ha Aden. (2016). Somali Pastoralism In Transition From Traditional To Modern Methods Of Livestock Keeping: A case study of Somali pastoralists In Wajir County. Retrieved November 2017 from http://erepository.uonbi.ac.ke/xmlui/bitstream/handle/11295/100042/Abdirahman Somali\%20Pastoralism \%20In\%20Transition\%20From\%20Traditional\%20To\%20Modern\%20Methods\%200f\%20Livestock\%20Keeping \%20A\%20Case \%20Study \%200f\%20Somali\%20Pastoralists\%20ln\%20Wajir\%20County.pdf?sequence =1 1 isAllo wed $=y$

Adamson, Kyalo. (2015). The Transformation of Turkana: Traditional Architecture - A case study of homesteads in Lodwar town and its suburbs. Retrieved November 2017 from http://architecture.uonbi.ac.ke/sites/default/files/cae/builtenviron/architecture/final\%20draft.pdf

African Development Bank. (2017, 7 July). AfDB approves US\$1 million emergency relief grant to drought victims in Kenya. Retrieved November 2017 from https://www.afdb.org/fr/news-and-events/afdbapproves-us-1-million-emergency-relief-grant-to-drought-victims-in-kenya-17164/

Ayuko B.; and Tanja C. (December 2008). The Illusion of Inclusion: Women's access to rights in Northern Kenya. Retrieved November 2017 from

http://siteresources.worldbank.org/INTJUSFORPOOR/Resources/Chopra Illusion of Inclusion Womens A2 Rights in Northern Kenya.pdf

Cherono, Stella. (2016, 16 November). Cattle rustling blamed for illegal firearms among pastoralists. Daily Nation. Retrieved November 2017 from http:/ / www.nation.co.ke/news/Cattle-rustling-to-blame-forillegal-firearms-among-pastoralists/1056-3454526-rn3m30/index.html

Eneyew, A.; Mengistu, S. (2013). Double Marginalized Livelihoods: Invisible gender inequality in pastoral societies. Societies, 3, 104-116. Retrieved November 2017 from http://www.mdpi.com/2075-4698/3/1/104

Institute for Security Studies. (2011, 18 January). The Cycle of Drought in Kenya a Looming Humanitarian Crisis. Retrieved November 2017 from https://issafrica.org/iss-today/the-cycle-of-drought-in-kenya-alooming-humanitarian-crisis

Inter-agency Standing Committee. (December 2006). Women, Girls, Boys and Men: Different needs - equal opportunities. Retrieved November 2017 from

https://www.humanitarianresponse.info/system/files/documents/files/Gender\%20Handbook.pdf

Kenya National Bureau of Statistics. (March 2012). 2009 Kenya Population and Housing Census Analytical Reports: Analytical report on gender dimensions, volume XII. http:// www.worldcat.org/title/2009-kenyapopulation-and-housing-census/oclc/940545345? referer =disht=edition

Kidder, T.; Pionetti, C. (2013, 7 0ctober). Oxfam Rapid Care Analysis: Guidance for managers and facilitators. Retrieved November 2017 from https://policy-practice.oxfam.org.uk/publications/participatorymethodology-rapid-care-analysis-302415

Lyons, Kate. (2017, 5 July). Drought in Kenya drives girls as young as 12 to have sex for money. The Guardian. Retrieved November 2017 from https://www.theguardian.com/global-development/2017/jul/05/droughtkenya-drives-girls-as-young-as-12-to-have-sex-for-money-international-rescue-committeereport?CMP $=$ Share AndroidApp Copy to clipboard

Makong, Bruhan. (2017, 9 May). Kenya: Beliefs prevent women from seeking political positions. Daily Nation. Retrieved November 2017 from http://allafrica.com/stories/201705100200.html

Nyamori, Moses. (2016, 14 April). 650,000 illegal firearms in circulation in Kenya, report reveals. Standard Digital. Retrieved November 2017 from https:// www.standardmedia.co.ke/article/2000198259/650-000illegal-firearms-in-circulation-in-kenya-report-reveals

Niamir-Fuller, M. (2000). Managing Mobility in African Rangelands. Property Rights, Risk, and Livestock Development in Africa, ed. N. McCarthy, B. Swallow, M. Kirk, and P. Hazell. 102-31. Washington, DC: 
International Food Policy Research Institute. Retrieved November 2017 from http://www.worldagroforestry.org/downloads/Publications/PDFS/B10973.pdf

Onchiri, Edna. (2017, 4 Aprill. Providing Emergency Support to Drought-Stricken Northern Region of Kenya. Beyond. Retrieved November 2017 from http://www.feedthechildren.org/2017/04/providing-emergencysupport-to-drought-stricken-northern-region-of-kenya/

Opiyo, F., Wasonga, O., Nyangito, M. et al. (September 2015). Drought Adaptation and Coping Strategies Among the Turkana Pastoralists of Northern Kenya. International Journal of Disaster Risk Science, 6(3), 295309. Retrieved November 2017 from https://doi.org/10.1007/s13753-015-0063-4

Oxfam, Save The Children. (2012, 18 January). A Dangerous Delay: The cost of late response to early warnings in the 2011 drought in the Horn of Africa. Retrieved November 2017 from https: / / policypractice.oxfam.org.uk/publications/a-dangerous-delay-the-cost-of-late-response-to-early-warnings-inthe-2011-droug-203389

Psirmoi, Daniel. (2017, 7 April). Man wants bhang use made legal in Kenya. Standard Digital. Retrieved November 2017 from https:// www.standardmedia.co.ke/article/2001235352/man-wants-bhang-usemade-legal-in-kenya

Relief Web. Kenya: Drought 2014-2017. Retrieved November 2017 from http://reliefweb.int/disaster/dr$\underline{2014-000131-k e n}$

Save The Children. Acute Malnutrition Summary Sheet. Retrieved November 2017 from http://www.savethechildren.org/atf/cf/\%7B9def2ebe-10ae-432c-9bd0-df91d2eba74a\%7D/AcuteMalnutrition-Summary-Sheet.pdf

Schilling, Janpeter et al. (2012). Raiding pastoral livelihoods: Motives and effects of violent conflict in northwestern Kenya. Retrieved November 2017 from https://pastoralismjournal.springeropen.com/articles/10.1186/2041-7136-2-25

Swift, J. (2001). District-level drought contingency planning in arid districts of Kenya. Pastoralism, Drought and Planning: Lessons from northern Kenya and elsewhere, ed. J. Morton. 40-84. Chatham: Natural Resources Institute.

UN Office for the Coordination of Humanitarian Affairs. (2017, 8 March). Horn of Africa: Impact of conflict and drought crises on women and girls. Retrieved November 2017 from

https://reliefweb.int/report/somalia/horn-africa-impact-conflict-and-drought-crises-women-and-girlsmarch-2017

UN Office for the Coordination of Humanitarian Affairs. (26 May 2017). Kenya: Humanitarian Dashboard. Retrieved November 2017 from https://reliefweb.int/report/kenya/kenya-humanitarian-dashboard-26$\underline{\text { may-2017 }}$

United Nations Statistics Division. (2015). The World's Women 2015. Retrieved November 2017 from https://unstats.un.org/unsd/gender/worldswomen.html

Watson, D., and J. van Binsbergen. (2006). Life Beyond Pastoralism: Livelihood diversification opportunities for pastoralists in Turkana District, Kenya. Retrieved November 2017 from

https://cgspace.cgiar.org/handle/10568/580

World Bank Group. (October 2015). Kenya Agricultural Risk Assessment. Retrieved November 2017 from http://documents.worldbank.org/curated/en/380271467998177940/pdf/100299-BRI-P148139-PUBLICBox393227B-Kenya-Policy-Note-web.pdf

World Economic Forum. (2015, 2 November). Do women work longer hours than men? Retrieved November 2017 from https:// www.weforum.org/agenda/2015/11/do-women-work-longer-hours-than-men/ 


\section{NOTES}

1 African Development Bank. (2017, 7 July). AfDB approves USS1 million emergency relief grant to drought victims in Kenya. Retrieved November 2017 from https://www.afdb.org/fr/news-and-events/afdb-approves-us-1-millionemergency-relief-grant-to-drought-victims-in-kenya-17164/

2 UN Office for the Coordination of Humanitarian Affairs. (2017, 26 May). Kenya: Humanitarian Dashboard. https://reliefweb.int/report/kenya/kenya-humanitarian-dashboard-26-may-2017

3 lbid.

4 Oxfam. Kenya Drought Response Campaign and Advocacy Strategy. (March 2017). Unpublished document.

5 African Development Bank. (2017, 7 July). AfDB approves USS1 million emergency relief grant to drought victims in Kenya. Retrieved November 2017 from https://www.afdb.org/fr/news-and-events/afdb-approves-us-1-millionemergency-relief-grant-to-drought-victims-in-kenya-17164/

6 Save The Children. Acute Malnutrition Summary Sheet. Retrieved November 2017 from http://www.savethechildren.org/atf/cf/\%7B9def2ebe-10ae-432c-9bd0-df91d2eba74a\%7D/Acute-MalnutritionSummary-Sheet.pdf

7 UN Office for the Coordination of Humanitarian Affairs. (2017, 26 May). Kenya: Humanitarian Dashboard. Retrieved November 2017 from https://reliefweb.int/report/kenya/kenya-humanitarian-dashboard-26-may-2017

$8 \mathrm{lbid}$.

9 Oxfam, Save The Children. (2012, 18 January). A Dangerous Delay: The cost of late response to early warnings in the 2011 drought in the Horn of Africa. Retrieved November 2017 from https: / / policypractice.oxfam.org.uk/publications/a-dangerous-delay-the-cost-of-late-response-to-early-warnings-in-the2011-droug-203389

10 Institute for Security Studies. (2011, 18 January). The Cycle of Drought in Kenya a Looming Humanitarian Crisis. Retrieved November 2017 from https://issafrica.org/iss-today/the-cycle-of-drought-in-kenya-a-loominghumanitarian-crisis

11 World Bank Group. (October 2015). Kenya Agricultural Risk Assessment. Retrieved November 2017 from http://documents.worldbank.org/curated/en/380271467998177940/pdf/100299-BRI-P148139-PUBLICBox393227B-Kenya-Policy-Note-web.pdf

12 Opiyo, F., Wasonga, 0., Nyangito, M. et al. (September 2015). Drought Adaptation and Coping Strategies Among the Turkana Pastoralists of Northern Kenya. International Journal of Disaster Risk Science, 6(3), 295-309. Retrieved November 2017 from https://doi.org/10.1007/s13753-015-0063-4

13 Inter-agency Standing Committee. (December 2006). Women, Girls, Boys and Men: Different needs - equal opportunities. Retrieved November 2017 from https://www.humanitarianresponse.info/system/files/documents/files/Gender\%20Handbook.pdf

14 Kenya National Bureau of Statistics. Population and Housing Census 2009 file:///C:/Users/rbonnemel/Downloads/Volume\%202-

Population\%20and\%20Household\%20Distribution\%20by\%20Socio-Economic\%20Characteristics.pdf

15 Eneyew, A.; Mengistu, S. (2013). Double Marginalized Livelihoods: Invisible gender inequality in pastoral societies. Societies, 3, 104-116. Retrieved November 2017 from http://www.mdpi.com/2075-4698/3/1/104

16 There seems to be a debate among Muslims if women are allowed to slaughter animals or not. In Wajir, FGD participants said that they are not allowed. However, Muslim scholars say that either women or men can slaughter animals. Retrieved November 2017 from https://islamqa.info/en/1913

17 Fiona Flintan. (December 2011). The Changing Nature of Gender Roles in the Drylands of the Horn and East Africa: Implications for DRR programming. Retrieved November 2017 from http://www.preventionweb.net/publications/view/24271

18 United Nations Statistics Division. (2016). The World's Women 2015. Retrieved November 2017 from https://unstats.un.org/unsd/gender/worldswomen.html

19 World Economic Forum. (2015, 2 November). Do women work longer hours than men?Retrieved November 2017 from https://www.weforum.org/agenda/2015/11/do-women-work-longer-hours-than-men/

20 Kidder, T.; Pionetti, C. (2013, 7 October). Oxfam Rapid Care Analysis: Guidance for managers and facilitators. Retrieved November 2017 from https://policy-practice.oxfam.org.uk/publications/participatory-methodology-rapid-careanalysis-302415

21 Ayuko B.; and Tanja C. (December 2008). The Illusion of Inclusion: Women's access to rights in Northern Kenya. Retrieved November 2017 from http://siteresources.worldbank.org/INTJUSFORPOOR/Resources/Chopra Illusion of Inclusion Womens A2 Rights in_Northern_Kenya.pdf 
22 In Kenya, Oxfam has been active in campaigning for women to be more represented in political spaces.

23 Some organizations that are working in Turkana and Wajir on women or child protection interventions leither directly or indirectly) include IRC, Mercy Corps, Child Fund and Save the Children. IRC is supporting a women's wellness centre in Turkana where GBV survivors can receive support. Mercy Corps has been supporting the county government to strengthen its GBV referral pathways. Local NGOs who are also supporting women and children include Kenya Red Cross, Diocese of Lodwar and TWCC.

24 This assessment was done a year after the drought began. Most of the respondents had already lost many animals. Those with animals continued to search for better pastures, but many were forced to shift to other livelihood options, such as starting or expanding petty trading, or engaging in manual labour. Some became involved in harmful and/or illegal activities such as prostitution, forced marriage, stealing, etc., or activities that run counter to traditional roles as explained above. (See also the section on coping strategies.)

25 Opiyo, F., Wasonga, 0., Nyangito, M. et al. (September 2015). Drought Adaptation and Coping Strategies Among the Turkana Pastoralists of Northern Kenya. International Journal of Disaster Risk Science, 6(3), 295-309. Retrieved November 2017 from https://doi.org/10.1007/s13753-015-0063-4

26 UN Office for the Coordination of Humanitarian Affairs. (2017, 8 March). Horn of Africa: Impact of conflict and drought crises on women and girls. Retrieved November 2017 from https://reliefweb.int/report/somalia/horn-africaimpact-conflict-and-drought-crises-women-and-girls-march-2017

27 Onchiri, Edna. (2017, 4 April). Providing Emergency Support to Drought-Stricken Northern Region of Kenya. Beyond. Retrieved November 2017 from http://www.feedthechildren.org/2017/04/providing-emergency-support-todrought-stricken-northern-region-of-kenya/

28 'There is no woman who takes off her garments anywhere but in the house of her husband, but she has torn the veil that is between her and her Lord.' Classed as saheeh by al-Albaani in Saheeh al-Tirmidhi. But if she cannot bathe in the house, then it is permissible for her to go to the public baths as a matter of necessity, but she must be careful and keep herself covered. Retrieved November 2017 from https:/ islamqa.info/en/93935

29 Retrieved November 2017 from https://islamqa.info/en/70438

30 Lyons, Kate. (2017, 5 July). Drought in Kenya drives girls as young as 12 to have sex for money. The Guardian. Retrieved November 2017 from https:// www.theguardian.com/global-development/2017/jul/05/drought-kenyadrives-girls-as-young-as-12-to-have-sex-for-money-international-rescue-committeereport?CMP $=$ Share AndroidApp Copy to clipboard

31 Abdirahman, Fat-Ha Aden. (2016). Somali Pastoralism In Transition From Traditional To Modern Methods Of Livestock Keeping: A case study of Somali pastoralists In Wajir County. Retrieved November 2017 from http://erepository.uonbi.ac.ke/xmlui/bitstream/handle/11295/100042/Abdirahman Somali\%20Pastoralism\%20ln\%2 0Transition\%20From\%20Traditional\%20T0\%20Modern\%20Methods\%200f\%20Livestock\%20Keeping\%20A\%20Case \%20 Study\%200f\%20Somali\%20Pastoralists\%20In\%20Wajir\%20County.pdf?sequence=18isAllowed =y

32 In Turkana, 30,000 pastoralists were reported to have moved to Uganda in January 2017. Honorine Sommet-Lange (Head of Sub-Office, UNHCR Kakuma Refugee Camp), said they were monitoring the movement as there were reports that the pastoralists were planning to move back because of difficulties in Uganda. The Governments of Kenya and Uganda have agreed to support the pastoralists' stay in Uganda to avoid further inter-border conflicts, as well as potential refugee-IDP conflicts in Kakuma. Cattle rustling, according to the Regional Centre on Small Arms, has evolved from a traditional practice to a commercial one, thus escalating violence. A report by the organization said the commercialization of cattle-rustling had pushed pastoralist communities to acquire guns for theft and for protecting their stocks.

Cherono, Stella. (2016, 16 November). Cattle rustling blamed for illegal firearms among pastoralists. Daily Nation. Retrieved November 2017 from http:// www.nation.co.ke/ news/Cattle-rustling-to-blame-for-illegal-firearmsamong-pastoralists/1056-3454526-rn3m30/index.html

33 Legalization of bhang in Kenya is currently under legislative discussion, as its production and use is common. Psirmoi, Daniel. (2017, 7 April). Man wants bhang use made legal in Kenya. Standard Digital. Retrieved November 2017 from https:// www.standardmedia.co.ke/article/2001235352/man-wants-bhang-use-made-legal-in-kenya

34 As explained in Klls (anonymous for security reasons).

35 Swift, J. (2001). District-level drought contingency planning in arid districts of Kenya. Pastoralism, Drought and Planning: Lessons from northern Kenya and elsewhere, ed. J. Morton. 40-84. Chatham: Natural Resources Institute; Watson, D., and J. van Binsbergen. (2006). Life Beyond Pastoralism: Livelihood diversification opportunities for pastoralists in Turkana District, Kenya. Retrieved November 2017 from https://cgspace.cgiar.org/handle/10568/580

36 Schilling, Janpeter et al. (2012). Raiding pastoral livelihoods: Motives and effects of violent conflict in north-western Kenya. Retrieved November 2017 from https://pastoralismjournal.springeropen.com/articles/10.1186/2041-71362-25 
37 Opiyo, F., Wasonga, O., Nyangito, M. et al. (September 2015). Drought Adaptation and Coping Strategies Among the Turkana Pastoralists of Northern Kenya. International Journal of Disaster Risk Science, 6(3), 295-309. Retrieved November 2017 from https://doi.org/10.1007/s13753-015-0063-4

$38 \mathrm{lbid}$.

39 Niamir-Fuller, M. (2000). Managing Mobility in African Rangelands. Property Rights, Risk, and Livestock Development in Africa, ed. N. McCarthy, B. Swallow, M. Kirk, and P. Hazell. 102-31. Washington, DC: International Food Policy Research Institute. Retrieved November 2017 from http://www.worldagroforestry.org/downloads/Publications/PDFS/B10973.pdf

40 Opiyo, F., Wasonga, 0., Nyangito, M. et al. (September 2015). Drought Adaptation and Coping Strategies Among the Turkana Pastoralists of Northern Kenya. International Journal of Disaster Risk Science, 6(3), 295-309. Retrieved November 2017 from https://doi.org/10.1007/s13753-015-0063-4

41 In March 2014, the Kenyan parliament adopted the Marriage Act 2014, which introduces a uniform minimum age of marriage, set at 18 for both women and men. However, an estimated 23\% of girls are married before their 18th birthday in Kenya. (UNICEF 2016: State of the World's Children.)

42 Refer also to Oxfam's Protection Assessment.

43 Adamson, Kyalo. (2015). The Transformation of Turkana: Traditional Architecture - A case study of homesteads in Lodwar town and its suburbs. Retrieved November 2017 from http://architecture.uonbi.ac.ke/sites/default/files/cae/builtenviron/architecture/final\%20draft.pdf

44 Nyamori, Moses. (2016, 14 April). 650,000 illegal firearms in circulation in Kenya, report reveals. Standard Digital. Retrieved November 2017 from https:// www.standardmedia.co.ke/article/2000198259/650-000-illegal-firearmsin-circulation-in-kenya-report-reveals

45 Kenya National Bureau of Statistics. (March 2012). 2009 Kenya Population and Housing Census Analytical Reports: Analytical report on gender dimensions, volume XII. 